\title{
ASSESSING SENIORS' PERSPECTIVES TOWARDS RIDE FOR FREE PUBLIC TRANSPORTATION: A CASE STUDY IN OAKVILLE, ONTARIO
}

\author{
by \\ Stephanie Mah \\ BA, University of Alberta, 2012 \\ A Master's Research Paper \\ presented to Ryerson University \\ in partial fulfillment of the \\ requirements for the degree of \\ Masters of Planning \\ in the Program of \\ Urban Development \\ Toronto, Ontario, Canada, 2015 \\ (C) Stephanie Mah, 2015
}




\section{AUTHOR'S DECLARATION}

I hereby declare that I am the sole author of this Masters Research Paper (MRP). This is a true copy of the MRP, including any required final revisions.

I authorize Ryerson University to lend this MRP to other institutions or individuals for the purpose of scholarly research.

I further authorize Ryerson University to reproduce this MRP by photocopying or by other means, in total or in part, at the request of other institutions or individuals for the purpose of scholarly research. I understand that my MRP may be made electronically available to the public. 


\title{
ASSESSING SENIOR PERSPECTIVES' TOWARDS RIDE FOR FREE PUBLIC TRANSPORTATION: A CASE STUDY IN OAKVILLE, ONTARIO
}

\author{
by \\ (C) Stephanie Mah, 2015 \\ Master of Planning in Urban Development \\ Ryerson University
}

\begin{abstract}
This research investigated the Ride for Free Public Transportation program for seniors in Oakville, Canada. Using a mixed-methods approach, participants were surveyed $(n=131)$ to understand their travel behaviour, and interviewed $(n=16)$ to understand their perspectives towards taking public transportation. While $63 \%$ of seniors said that the Ride for Free Transit Program did not impact their travel behaviour, 37\% said that it increased their public transit use. The most popular reason for seniors to use public transportation was taking it by themselves. Some interview respondents said that they used public transportation because they would not have to ask others for rides or they did not have access to a car. Seniors suggested that more education of how to use the bus and transfer could increase senior ridership. This research may aid other municipalities considering similar programs, which could help to sustain the independent mobility of seniors.
\end{abstract}

Keywords: Seniors, aging, public transportation, driving, perspectives, behaviour, mixedmethod approach 


\section{ACKNOWLEDGEMENTS}

The completion and success of this research could not have been achieved without the guiding efforts of Dr. Raktim Mitra at Ryerson University. His mentorship, advice, time, constructive feedback, and expertise were instrumental in the development of this project over the past two years at Ryerson University. I would like to thank him for his motivation and for being there whenever I needed.

I would like to thank Amy Shepherd from IBI Group for being the Second Reader of my Final Draft Paper and for her professional opinion and keen attention to detail which assisted with my final edits.

In addition, the strong support from the Oakville Community Senior Services Centre that I received greatly contributed to the success of this research. I would like to sincerely thank the Town of Oakville staff, Nancy Beddoe, Maggie Gibb, Julie Pennal, and Karen Waid, for welcoming me into the community, and their kindness and attentiveness towards my research needs.

I would also like to thank Joan Phoenix from Oakville Transit for her support and help in sending me data.

Furthermore, the strong participation and positivity that I received from the Oakville senior community could not go unnoticed. I will look back on my MRP and remember the delightful participants who assisted me with my survey and interviews. My MRP would not have been nearly as interesting without their personal experiences and feedback. 


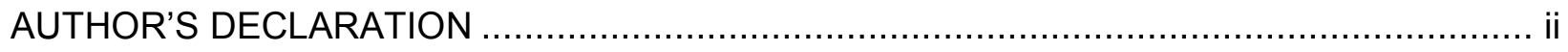

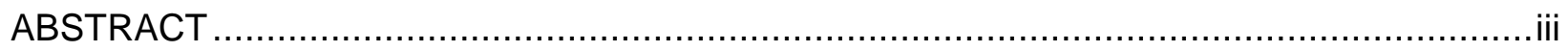

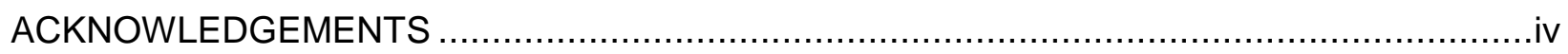

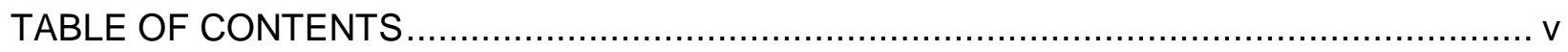

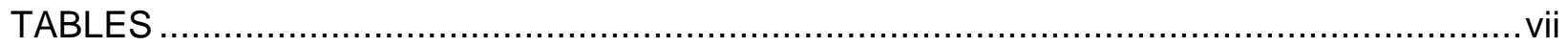

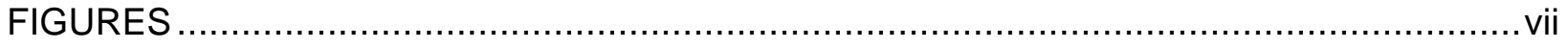

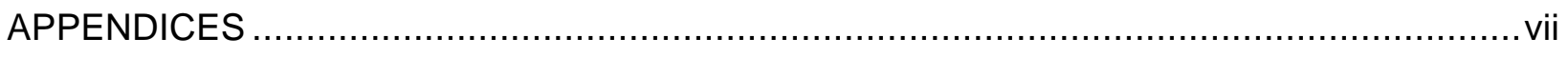

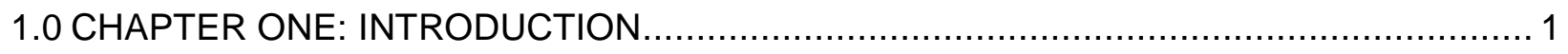

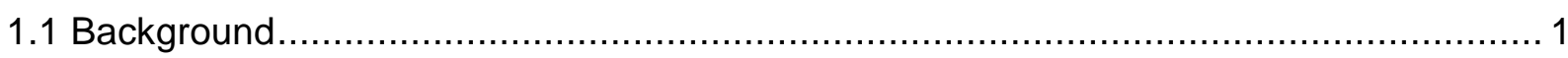

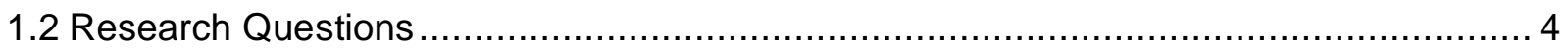

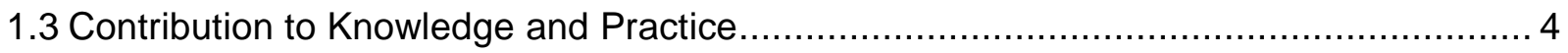

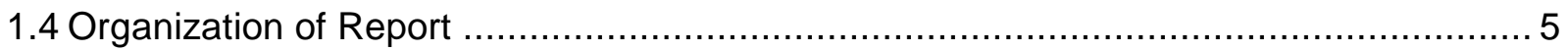

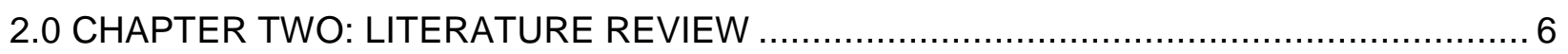

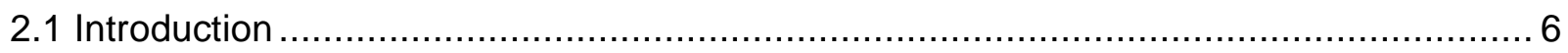

2.2 The Current State of Senior Mobility in the Suburbs .............................................. 6

2.3 The Importance of Public Transportation for Seniors.............................................. 7

2.4 Senior Travel Behaviour Focusing on Public Transportation..................................... 7

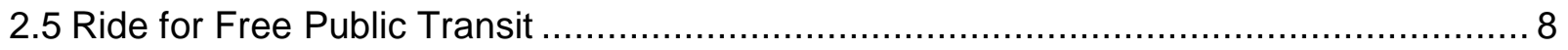

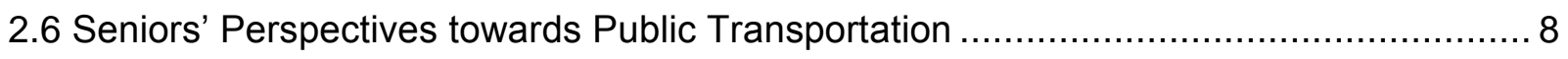

2.7 Ride for Free Transit Pilot Program in Oakville ................................................... 10

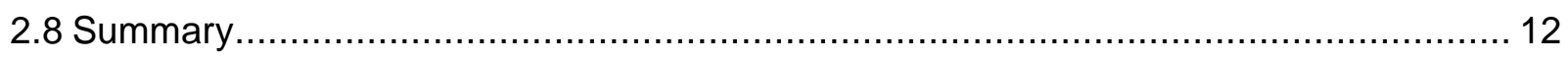

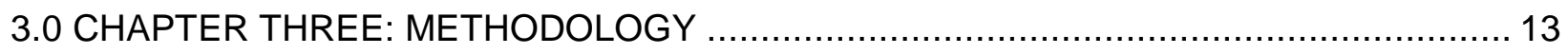

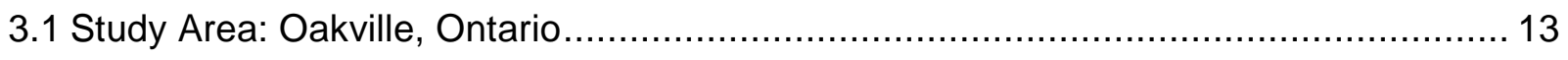

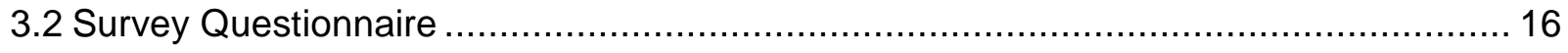

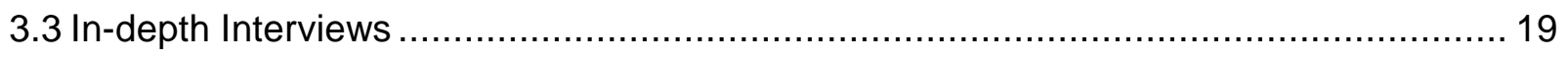

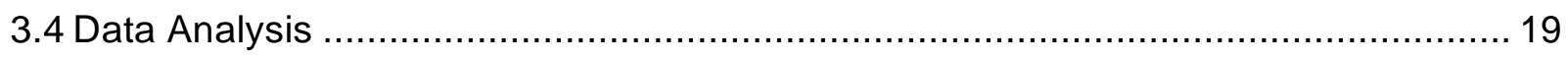

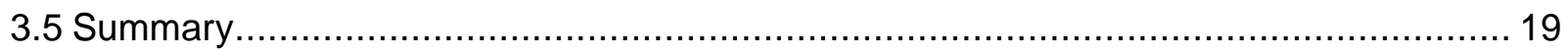

4.0 CHAPTER FOUR: THE EFFECTS OF THE RIDE FOR FREE TRANSIT PROGRAM ON

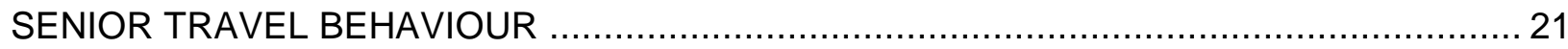

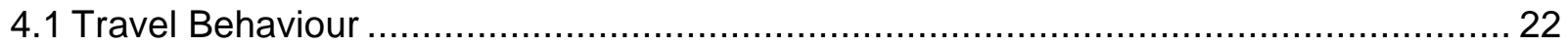

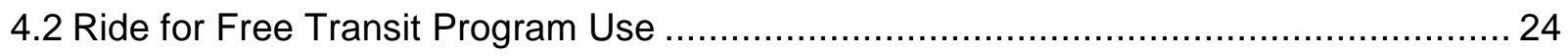

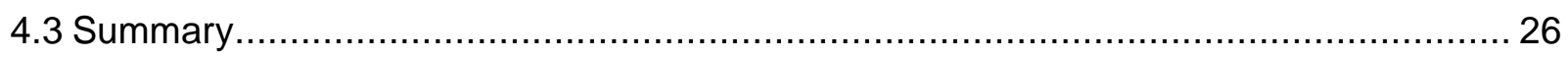

5.0 CHAPTER FIVE: SENIORS' PERSPECTIVES ON PUBLIC TRANSPORTATION ............ 27

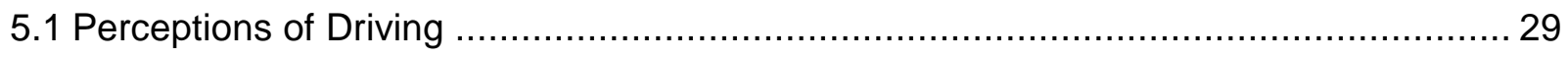


5.2 Perceptions of Public Transportation ........................................................ 30

5.3 Experience with the Ride for Free Transit Program ........................................... 32

5.4 Improving the Ride for Free Transit Program ........................................... 33

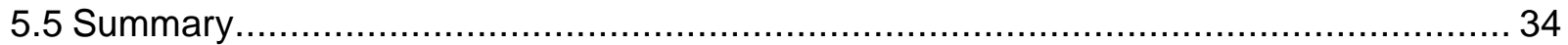

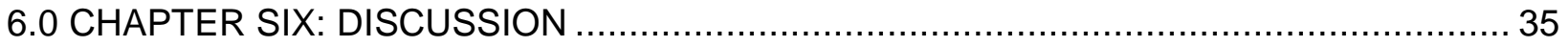

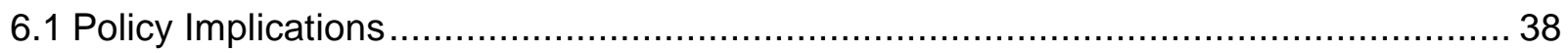

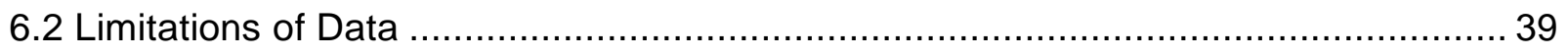

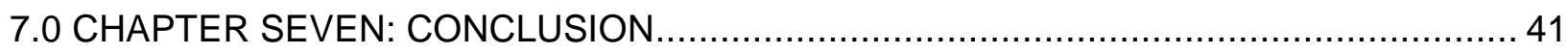

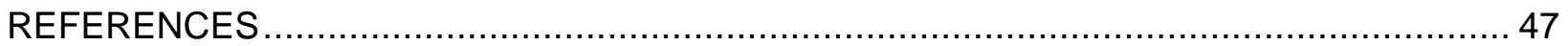




\section{TABLES}

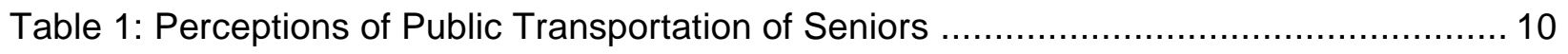

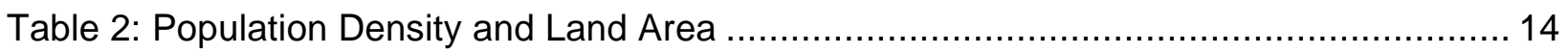

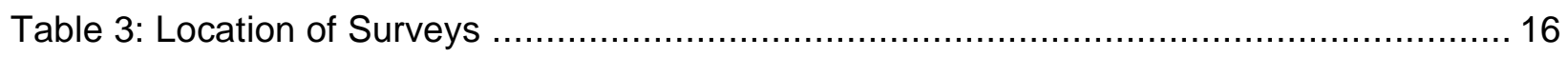

Table 4: Demographic Characteristics of Survey Participants .......................................... 21

Table 5: Ride for Free Transit Program Impact on Travel Behaviour..................................... 25

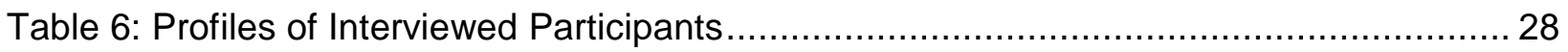

\section{FIGURES}

Figure 1: Senior Ridership Numbers in Oakville from 2007-2012 ….............................. 10

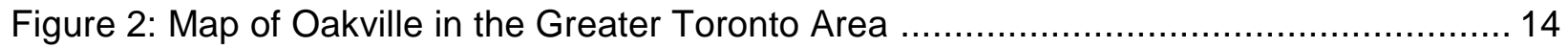

Figure 3: Comparison of Senior Population by Age Groups in the Town of Oakville .............. 15

Figure 4: Location of Participants by Ward................................................................. 18

Figure 5: Frequency of Personal Vehicle Use ........................................................... 22

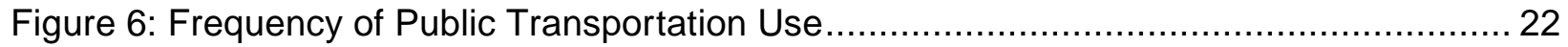

Figure 7: Reasons for Taking Public Transportation ......................................................... 23

Figure 8: Reasons for Not Taking Public Transportation................................................. 24

Figure 9: Impact on Participant if Program Stopped .................................................... 24

Figure 10: Ride for Free Transit Program Impact on Travel Behaviour .............................. 25

\section{APPENDICES}

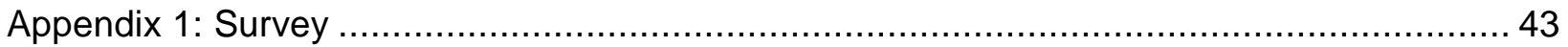

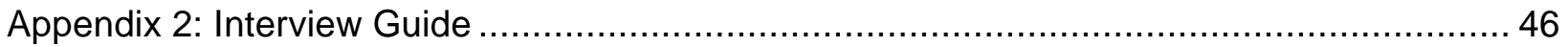




\subsection{CHAPTER ONE: INTRODUCTION}

\subsection{Background}

Over $80 \%$ of Canadian seniors, those over 65 years of age (Statistics Canada, 2006), live in cities (Hodge, 2008; Public Health Agency of Canada, 2010; Federation of Canadian Municipalities, 2013). By 2036, seniors will account for $25 \%$ of the Canadian population (Newbold et al., 2005; Páez et al., 2007; Federation of Canadian Municipalities; 2013). Currently, the majority of the working age (30-64 years old) live in low density suburban developments (Rosenbloom, 2001; Scott et al., 2005), which are typically characterised by separated land uses and meandering hierarchical street networks that favour automobile use (Cao et al., 2010). Recent research indicates that many of seniors and the working age population are opting to "age in place," which is to continue living in their homes or communities because they perceive it to be safer, more comfortable, and are more independent in their later years (Hodge, 2008; Turcotte, 2012; Franke et al., 2013; Ewing \& Bartholomew, 2013; Federation of Canadian Municipalities, 2013; Northcott \& Petriuk, 2013). Furthermore, most seniors do not migrate over substantial distances from suburban to urban areas when they downsize their homes (Kim, 2011). This trend indicates that suburban municipalities across Canada may be disproportionately affected by an increased senior population in the coming decades (Ladd, 2012). This phenomenon places responsibility on suburban municipalities to accommodate for the diverse needs of seniors such as transportation.

Given the suburban built environments that many seniors live in, most seniors identify the car as their main form of transportation because it is a lifestyle that they are familiar with (Rosenbloom, 2001; Alsnih \& Hensher, 2003; Newbold et al., 2005; Páez et al., 2007; Cao et al., 2010; Ladd, 2012; Kim, 2011; Turcotte, 2012), it is a symbol of non-elderly status (Alsnih \& Hensher, 2003; Davey, 2007), and it provides quick access to social, leisure and health services (Ladd, 2012). Research indicates that seniors today have a tendency to drive more than a decade ago (Rosenbloom, 2001).

Research also indicates that seniors without access to or who cannot afford a car in a suburban environment were prone to a declining quality of life (Cao et al., 2010), were more isolated and less social (Alsnih \& Hensher, 2003; Davey, 2007; Ladd, 2012). As seniors age, 
their cognitive and physical ability to drive will decrease (Ladd, 2012). Existing research also reported that the physical and mental well-being of a senior was tied to their independence and ability to move around by car (Cvitkovich \& Wister, 2001; Turcotte, 2006; Davey, 2007; Hodge, 2008; Scott et al., 2009). Moreover, the frequent dependence on friends and family for transportation was damaging to a senior's mental health because they felt like a burden (Hodge, 2008), which contributed to feelings of anxiety or depression.

From the literature, it is not surprising that access to transportation appears to be one of the key ingredients in maintaining a senior's mental health because it results in independence and freedom, but it can also improve physical health. Research shows that seniors are at a higher risk of developing chronic illnesses such as cardiovascular diseases, osteoarthritis, asthma, diabetes, obesity, weight gain, decreased muscle strength, and decreased aerobic capacity by engaging in sedentary behaviours (Chaudhury et al., 2012; Kerr et al., 2012; Franke et al., 2013) such as driving. From this context, alternative transportation options such as public transportation (transit) may fill an important role of maintaining independence and mental and physical well-being for some seniors (Newbold et al., 2005; Hodge, 2008; Coronini-Cronberg et al., 2012).

It is important to understand that the majority of seniors are less inclined to use public transportation because it has not been traditionally convenient for non-work travel in a suburban environment (Rosenbloom, 2001). In addition, some seniors have a stigma towards public transportation and only use it as a last resort (Smith \& Hiltner, 1988; Alsnih \& Hensher, 2003; Davey, 2007; Jones et al., 2013). However, public transportation has been shown to be a potentially attractive and important alternative to driving for some seniors who cannot drive due to health decline or who do not have access to a car (Smith \& Hiltner, 1988; Kerr et al., 2012). The availability of a public transportation network in a municipality can greatly influence the physical activity and quality of life of seniors (Kerr et al., 2012). For example, increased walking to and from bus stops can help seniors accumulate their recommended daily physical activity, help to maintain their mobility independence (Hodge, 2008; Coronini-Cronberg et al., 2012; Kerr et al., 2012), and help to maintain their quality of life - meaning the ability to meet one's personal needs that they were used to when they drove (Spinney et al., 2009).

Some studies have suggested that encouraging a shift of senior travel behaviour from automobiles to transit could be accomplished through providing incentives (Rosenbloom, 
2001). Some Western countries such as the United Kingdom (UK) have introduced ride for free transportation programs using free bus passes for seniors over 60 years of age. This provides public transportation at no cost every day or at specific times during the week and enables the use of alternative transportation options among seniors given the effects of decreased mobility on seniors' health, independence, and quality of life. Coronini-Cronberg et al. (2012) found that the bus pass significantly encouraged the frequency of bus trips and active transportation levels in seniors than those without a pass.

In Canada, free public transportation for seniors is not a new concept. For example, senior ride for free transportation programs occurred in the 1980s in Edmonton, Alberta (George, 2000). However, the feasibility of providing seniors with free transportation has been a dilemma for municipalities. While some argue that the bus will be empty during most of the day and should be used to give free rides to seniors, some would counter that the public transportation revenue from seniors is vital to maintain the transit operating costs (CoroniniCronberg et al., 2012).

More recently in Canada, there has been a resurrection of ride for free transit programs. In 2010, the House of Commons attempted to pass an act that would allow free public transit for seniors (Bill C-449) across Canada (Open Parliament, n.d.). Despite transportation being a provincial and municipal matter, Members of Parliament argued for the community benefits of free transit for seniors such as the reduction of gas emissions from vehicles, maintaining seniors' health through active transportation and reducing their isolation, and creating more vibrant street life. The Bill was never passed for a third reading in 2011 (Open Parliament, n.d.).

In 2010, Ottawa, Ontario and Moncton, New Brunswick implemented ride for free transit programs on Wednesdays (OC Transpo, 2014; Codiac Transpo, 2014; Moore, 2010). In 2011, Halifax, Nova Scotia attempted a pilot project for three months, but it was deemed unfeasible (Lightstone, 2011). In the following year, Oakville, Ontario introduced their ride for free program on Mondays for seniors (Oakville Beaver, 2012). More recently, Laval, Quebec introduced a senior ride for free program at any time and any day starting in 2014 (Canada Newswire, 2014). 
While free transit programs are growing across Canada, their impacts on senior travel behaviour and perceptions have not been extensively reviewed. Moreover, the limited literature conducted on Canadian seniors using free public transportation in the suburban context spurs a need for more research on this topic with the increasing presence of these Ride for Free Transit Programs recently becoming more popular.

\subsection{Research Questions}

Despite the existence of several programs across Canada, there has been limited research conducted on Ride for Free Transit Programs for seniors in Canada. Given the demographic trend of Canada's aging population particularly in suburban communities, systematic research on this topic can make an important contribution by enabling suburban municipalities reviewing the travel options for seniors and in working towards more age friendly cities (OPPI, 2009). In this context, the goal of this research is to explore the public transportation travel behaviour and perspectives of seniors towards free transportation programs using the case study for Oakville, Ontario. In particular, two research questions were examined:

1. How has a ride for free bus service for seniors affected auto-dependence and transit ridership among the senior population?

2. What are the perspectives of seniors towards public transportation in a suburban municipality?

\subsection{Contribution to Knowledge and Practice}

For planners and policy makers to improve public transportation policies and programs, they must first understand public transportation behaviours and perceptions to make informed decisions. There have been few studies conducted on senior perceptions and behaviours towards free public transportation specifically in suburban communities. This research will help to inform Canadian, and more broadly North American, municipalities who are exploring ways to improve their public transportation policies or programs for seniors. In due time, this research will help establish more accessible and affordable public transportation options, which may improve social integration in communities, increase mobility independence, and potentially improve the physical health of the Canadian senior population through increased active transportation. 


\subsection{Organization of Report}

This report is organized into seven chapters. Chapter One provides an introduction to the issues municipalities are facing in providing transportation services for seniors citizens. The research question and importance of research is established. Chapter Two presents a literature review on the current state of travel behaviour of senior mobility in the suburbs, the importance of public transportation for seniors, previous research on senior travel behaviour focusing on public transportation, the effect of Ride for Free Transit Programs on senior travel behaviour, senior perceptions towards public transportation, and survey results from the Town of Oakville Ride for Free Transit Pilot Program. Chapter Three explains the methodology approach taken for this mixed-methods research. Chapter Four delves into the key findings of the surveys focusing on senior travel behaviour in Oakville. Chapter Five explores the themes found from the in-depth interviews focusing on senior perspectives towards driving and public transit, and different user experiences using the Ride for Free Transit Program. Chapter Six analyzes the findings and themes of the results into a discussion that underscores the potential policy implications of this research, and lastly, Chapter Seven concludes this research. 


\subsection{CHAPTER TWO: LITERATURE REVIEW}

\subsection{Introduction}

Understanding alternative travel options for seniors can assist in the formation of age friendly cities, which are healthy, liveable, and accessible cities that support active participation among seniors (WHO, 2007). Increased average life expectancy of Canadians and the sheer size of the Baby Boomer cohort (those born from 1946-1964) (Statistics Canada, 2006) may place increased pressure on municipal services such as transportation (Hodge, 2008; Spinney et al., 2009). Providing current and future seniors with accessible, efficient, affordable, and safe transportation alternatives such as public transportation may have growing applicability in suburban municipalities when seniors will eventually be unable to physically drive due to health decline. This chapter summarizes findings from the existing literature that has explored the current state of senior mobility in the suburbs, the importance of public transportation for seniors, senior travel behaviour with a focus on public transportation, and lastly, seniors' perspectives towards public transportation. The literature review also includes the key findings from the Town of Oakville's Ride for Free Program Pilot Program in 2012.

\subsection{The Current State of Senior Mobility in the Suburbs}

Many seniors tend to exercise their leisure and recreational freedoms by taking care of family or friends, volunteering or working (Turcotte, 2006). Senior trip times have increased within the last decade (Alsnih \& Hensher, 2003) and it is predicted that seniors will contribute to the many vehicles on the road to meet their travel-activity patterns during regular work day hours and rush hour times (Alsnih \& Hensher, 2003; Hildebrand, 2003; Turcotte, 2006), which will increase traffic congestion levels and contribute to increased environmental pollution (Rosenbloom, 2001; Alsnih \& Hensher, 2003).

There are several reasons that explain an increase of seniors driving. Studies indicate that more seniors than ever before have driver's licenses (Rosenbloom, 2001), modern cars are manufactured to be easier to drive (Alsnih \& Hensher, 2003) (i.e. larger mirrors requiring less shoulder checking and strain on the body), seniors are more active and healthier since the expected life expectancy has increased, seniors enjoy larger disposable incomes, and seniors seem to resist changing their mode of transportation when they enter retirement (Alsnih \& Hensher, 2003). 
Moreover, the current layout of suburban municipalities decreases the appeal of public transportation for many seniors because they have to walk further distances to bus stops and wait (Kim, 2011). From a time efficiency standpoint, this reinforces the benefits of the private car by moving around more quickly, and decreases the appeal of taking public transport or an alternative mode of transportation (Alsnih \& Hensher, 2003). Hensher's (2007) study concluded that until there is a paradigm shift on how the suburban built environment can better prioritize public transportation over the car, public transportation in suburban locations is unlikely to keep up with seniors' demand of transportation needs as they age. Similarly, Scott et al. (2009) concluded that without suitable public transportation options, car dependence for seniors will only increase.

\subsection{The Importance of Public Transportation for Seniors}

The majority of seniors in suburban environments prefer the car as their main mode of transportation. However, the importance of public transportation cannot be neglected for some segments of the population. In particular the need for alternative transportation will be critical for seniors who can no longer physically drive, do not have a license, do not have a car or cannot afford a car, experience the passing of a partner who was the primary driver, or do not have access to a transportation network comprised of family, friends, or community members (Hensher, 2007; Kim, 2011). Public transportation has been found to be more popular with seniors who are over 75 years, are female, have lower social economic status, and live in more dense urban environments (Rosenbloom, 2001; Davey 2007). The lack of access to transportation can have major impacts on a senior's mental health (Hensher, 2007) and physical health (Franke et al., 2013).

\subsection{Senior Travel Behaviour Focusing on Public Transportation}

Some studies have looked at senior travel behaviour using public transit. One reason why public transportation has not been as popular among seniors is because traditional systems have not adapted to the current lifestyle of today's senior. A study found that even those who used public transportation before they retired, switched to the private automobile as their main mode of transportation (Alsnih \& Hensher, 2003). Perhaps the reason for this is that today's young seniors, aged 64-75 years of age, engage in trip chaining, which strings several shorter trips together so that seniors can participate in more activities (Alsnih \& Hensher, 2003). 
Engaging in this type of behaviour by public transportation may be fatiguing for a senior who does not leave their home as frequently as their counterparts that drive, and may be more difficult to do since conventional public transportation systems are not efficiently designed for this behaviour (Alsnih \& Hensher, 2003; Hensher, 2007). Alsnih and Hensher's (2003) study on seniors in Australia used data from the Sydney and Adelaide household travel survey and found a growing trend that seniors were driving more and using public transportation less. The study showed that the fixed routes for public transportation decreased the chance of switching senior travel behaviour from the car. The study concluded that meeting the mobility needs of seniors will be difficult since they are living longer and healthier lives and some will face mobility problems alone. As seniors age, policy makers, and planners will have to provide diverse services for a heterogonous group of seniors.

In another study, Kim (2011) found that when a senior stopped driving, their most preferred transportation alternative was receiving a ride with a friend or family, demonstrating that seniors prefer the automobile over any other alternative such as public transportation or walking. The findings show that seniors may consider using public transportation if transit access is within a ten minutes walking distance. The research showed that the seniors without any mobility issues were more likely to choose walking over public transportation. In addition, seniors who had limited exposure to public transportation or walking before they stopped driving could develop mobility problems (Kim 2011).

\subsection{Ride for Free Public Transit}

From conventional public transportation systems to incorporating incentives, Cronini-Cronberg (2012) reviewed the public health benefits associated with the UK's free bus pass for seniors in a longitudinal study. The study used data from the National Travel Survey and found that the seniors with a free bus pass had increased physical activity levels from walking a minimum of three times a week and their use of the bus increased. The study showed that older women over 70 years of age living in more urban areas with lower socio-economic status tended to use the free bus service the most. Having a free bus pass was correlated with an increased use of the bus. The number one factor that influenced bus travel behaviour was whether participants had access to a car.

\subsection{Seniors' Perspectives towards Public Transportation}


Even though there have been studies completed on seniors' perspectives towards public transportation highlighting positive and negative perceptions (see Table 1), there is still a knowledge gap of understanding the perspectives of public transportation for all types of seniors and what types of government intervention would be appropriate for specific groups (Alsnih \& Hensher, 2003).

There are many positive perceptions that seniors have towards public transportation. In another study done in the UK on free bus passes, Jones et al. (2013) found that seniors with the free bus passes gained entitlement by using public transportation, which further fostered their self-worth and social inclusion. Cao et al.'s (2010) study looked at how perceptions of neighbourhood design and the built form in northern California influenced the travel behaviour of seniors who drove, took public transportation, or walked. The findings indicated that many seniors perceived neighbourhoods with access to a public transportation network, paired with frequent service levels, could increase their mobility. Seniors without a driver's license or with physical mobility restrictions were shown to use public transportation ten times more than those with a driver's licence or without physical mobility restrictions (Cao et al., 2010). Positive perceptions towards public transportation included the enjoyment of using the service and it being easier to use than driving. In addition from other studies, seniors who utilized public transportation services felt that it was more cost effective than driving (Rosenbloom, 2001), they could maintain their independence, and they did not have to burden family or friends for a ride (Hodge, 2008).

On the other hand, the negative perceptions that seniors had towards public transportation seem to be more prevalent than the positive ones. Alsnih and Hensher (2003) found that the traditional scheduled public transportation service was not popular among seniors who were accustomed to a more flexible schedule when they drove; they tended to use public transportation as a last resort. Furthermore, the seniors who relied on public transportation were not satisfied with the fixed-route, fixed scheduling of the public transportation, time spent planning their trip (Alsnih \& Hensher, 2003) and long commute times (Rosenbloom, 2001). A study done by Rittner (1995) looked at the fears and attitudes of low socio-economic status seniors towards accessing medical care services by public transit in southern Florida. From a questionnaire, many of the respondents reported negative perceptions of the bus such as delayed service, lack of bus shelters, difficulty with getting on and off a crowded bus, concern 
over personal safety from crime or falling, dirty windows making it even harder to see with declining eye sight, and unsympathetic drivers and passengers (Rittner, 1995).

\begin{tabular}{|ll|}
\hline \multicolumn{2}{|c|}{ Table 1: Perceptions of Public Transportation of Seniors } \\
\hline Positive perceptions & Negative perceptions \\
\hline Cost-effective (Rosenbloom, 2001) & Long commute times (Rosenbloom, 2001) \\
\hline Maintain independence (Hodge, 2008) & Waiting for the bus (Alsnih \& Hensher, 2003) \\
\hline $\begin{array}{l}\text { Does not burden friends or family (Alsnih \& } \\
\text { Hensher, 2003; Hodge, 2008) }\end{array}$ & Fixed routes (Alsnih \& Hensher, 2003) \\
\hline Enjoy taking public transit (Cao et al., 2010) & Fixed scheduling (Alsnih \& Hensher, 2003) \\
\hline Easier to use than driving (Cao et al., 2010) & $\begin{array}{l}\text { Concern over personal safety (i.e. potential of } \\
\text { being a victim of crime or being injured from falling } \\
\text { on a moving bus) (Rittner, 1995) }\end{array}$ \\
\hline $\begin{array}{l}\text { Free bus service can foster self-worth and social } \\
\text { inclusion (Jones et al., 2013) }\end{array}$ & $\begin{array}{l}\text { Unwelcoming environment with a lack of bus } \\
\text { shelter stops and dirty bus windows (Rittner, } \\
1995)\end{array}$ \\
\hline & $\begin{array}{l}\text { Difficulty with entering and exiting the bus (Rittner, } \\
1995)\end{array}$ \\
\hline & $\begin{array}{l}\text { Unsympathetic drivers and disrespectful } \\
\text { passengers (Rittner, 1995) }\end{array}$ \\
\hline
\end{tabular}

\subsection{Ride for Free Transit Pilot Program in Oakville}

In 2012, the Town of Oakville implemented a 13-week "Free Transit for Seniors" Pilot Program for seniors over 65 allowing for free travel at no cost on Mondays. The Pilot Program results reported that senior ridership increased by $578 \%$ or by 12,917 trips on the same Mondays in 2011 (Oakville Transit, 2012). Figure 1 shows the dramatic increase of senior trips over the course of 13 Mondays from 2007 to 2012 (Oakville Transit, 2012) highlighting the positive impact of free transportation on senior ridership.

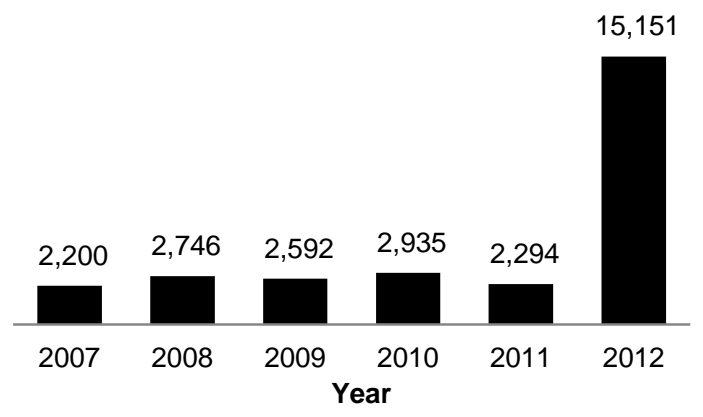

Figure 1: Senior Ridership Numbers in Oakville Over the Same 13 Mondays from 2007-2012 Adapted from Oakville Transit (2012)

Oakville Transit developed a survey to quantify the impacts of senior transportation usage after the Pilot Program, which was available at Town Hall, Oakville Transit, the Library and 
Community Centre locations, and online. A total of 219 surveys were completed with 71 surveys completed online and 148 completed on paper. The survey focused on the following themes (Oakville Transit, Budget Committee, 2012):

- Frequency of Oakville Transit use

- Time of day service was used and route taken

- Reasons for taking Oakville Transit

- Alternative days for the free transit day

Many respondents indicated that they were not regular riders of Oakville Transit, but $62 \%$ of riders had used the service before. Respondents usually used the bus in the morning from 9am-12pm. Their main reason for using the service was to go shopping or go to their medical appointments. It was found that Wednesday was the most popular alternative day for the free transit day for seniors. In addition, $75 \%{ }^{1}$ of respondents said that cost was a barrier to using the system. The survey also found that an increase in ridership was experienced across the system.

The Budget Report indicated that senior ridership on Tuesday averaged 531 rides per day (Oakville Transit, 2012), which was a $22.5 \%$ increase suggesting that the Pilot Program helped to retain people to ride the bus after the free day. From 2011, the ridership of seniors during the Pilot Program in 2012 increased by $11.4 \%$, which was an increase of 79,789 to 88,907 rides. The Budget Report pin pointed two main reasons why senior ridership had increased from 2011 to 2012, which was because of the Subsidized Passes for Low Income Transit (SPLIT) program and the Ride for Free Transit Program on Mondays (Oakville Transit, 2012). The SPLIT program ${ }^{2}$ provides low income students, adults and seniors with a regional subsidy for public transportation that covers at least $50 \%$ or more of the cost of a monthly transit pass (Halton Region, n.d.).

The results also provided some qualitative results from conversations with seniors. It was found that the Pilot Program offered some "soft benefits" that pertained to the quality of life. Some seniors indicated that they used the service to explore the town, visit friends, and go shopping at a mall when their alternative would have been to stay home. Oakville Transit estimated that the cost to continue the program would be $\$ 45,200$ (in 2012 dollars). The success of the Pilot Program was formalized into an annual program pending on funding during the budget process.

\footnotetext{
${ }^{1}$ It should be noted that $77 \%$ of respondents skipped this question (Oakville Transit, 2012).

${ }^{2}$ Eligibility of the SPLIT program is determined by Halton Region on a case-by-case basis (Halton Region, n.d.).
} 


\subsection{Summary}

With more seniors driving than ever before to meet their lifestyle patterns in the suburbs, this may have effects on road congestion and contribute to environmental pollution. Studies show that alternative transportation options such as public transportation are not as popular because they are on a fixed schedule and fixed route, which is currently unattractive for many seniors. Some seniors negatively perceived taking public transportation to be slow, detrimental to their personal safety, and an unpleasant experience with other members of the public. However, taking public transportation may become an attractive mode of transportation for those who no longer have access to a car. In some cases, public transportation can provide health benefits of increased walking accumulation. Some seniors positively perceived taking public transportation to be an enjoyable experience, be easier to use than driving, help them to maintain their independence and dignity, and reduce their dependence on family and friends for rides. Lastly, the Ride for Free Transit Pilot Program completed in Oakville resulted in a substantial increase in senior ridership one day a week when the program was offered. 


\subsection{CHAPTER THREE: METHODOLOGY}

This research studied the travel behaviour and perceptions of seniors towards the Ride For Free program in Oakville, Ontario. A case study was used to develop context specific knowledge of ride for free programs, which could guide other mid-sized suburban municipalities in Canada considering a similar program. This research adopted a mixed-methods approach, which involved short surveys and semi-structured in depth interviews. Mixed-method approaches can achieve a "synergistic set" (Greene, 1989, p. 257) that can strengthen the analysis of data using two different paradigms producing a more robust data set. The cross sectional surveys provided information on the participants travel behaviour. In conjunction, the interviews probed into seniors' perspectives towards ride for free transit programs because participants may utilize a "strengths perspectives," which uses an individual's "capacities, talents, competencies, possibilities, visions, values, and hopes, however dashed and distorted these may have become through circumstance" (Saleeby, 1996, p. 297).

Prior to any primary data collection, Ethics Approval was acquired from the Ryerson University's Research Ethics Board in August, 2014. In this study, senior population was defined as those over the age of 65 , which is consistent with Statistics Canada's (Turcotte, 2006) definition of senior and age requirements of the Town of Oakville's Ride for Free Transit Program (Oakville Transit, Budget Committee, 2012).

\subsection{Study Area: Oakville, Ontario}

In addition to Oakville, there are currently three other Canadian municipalities including Ottawa, Moncton and Laval that offer Ride for Free Program for seniors. The Town of Oakville was selected due its representative nature of a suburban municipality in terms of typical caroriented community, with separated land uses, and lower density dwellings. The Town is located approximately $35 \mathrm{~km}$ to the east of the City of Toronto and is situated along Lake Ontario in the southern portion of the Regional Municipality of Halton (Figure 2). 


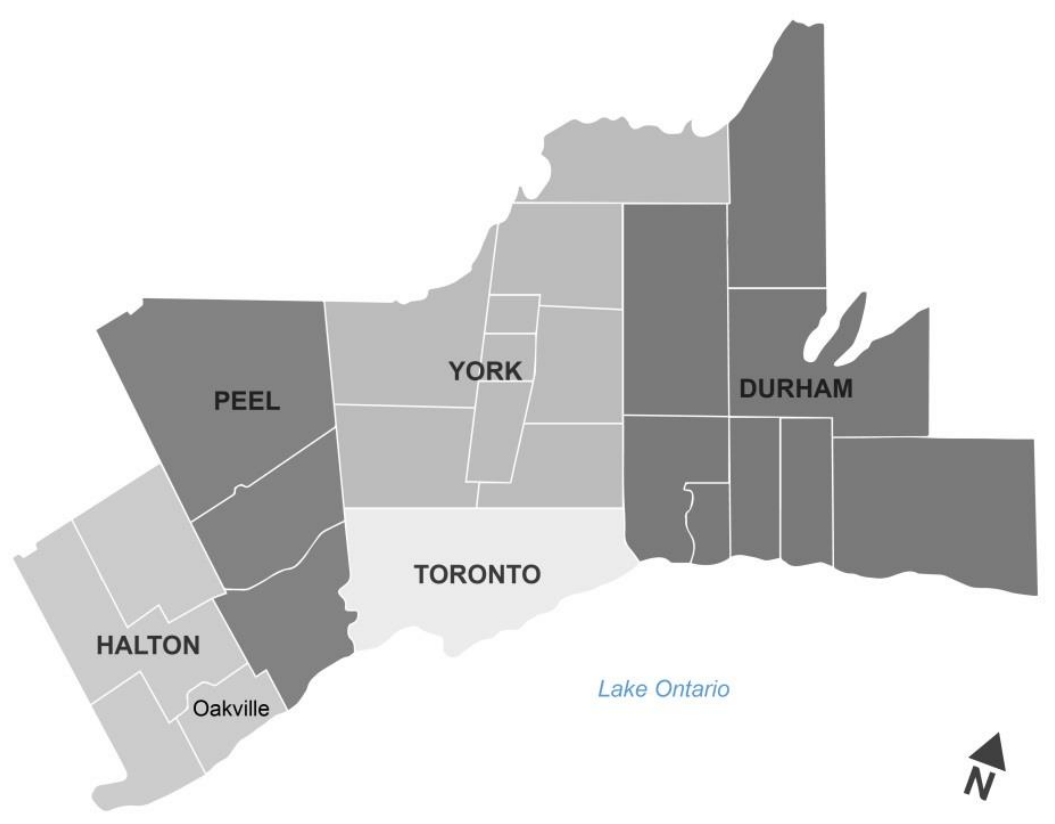

Figure 2: Map of Oakville in the Greater Toronto Area

The suburban nature of the Town of Oakville and Halton Region (Table 2) is characterised by the lower population densities compared to other "urban" centres such as the City of Toronto (Halton Region, 2007).

\begin{tabular}{|llll|}
\hline \multicolumn{4}{|c|}{ Table 2: Population Density and Land Area } \\
& Town of Oakville & Halton Region & City of Toronto \\
\hline Population & 182,520 & 501,669 & $2,615,060$ \\
\hline Population Density (persons $\left./ \mathrm{km}^{2}\right)$ & 1314.2 & 520.4 & $4,149.5$ \\
\hline Land area $\left(\mathrm{km}^{2}\right)$ & 138.88 & 964.01 & 630.21 \\
\hline
\end{tabular}

Source: Statistics Canada, 2011

The housing types are predominately single-detached dwellings in Oakville (63\%) (Statistics Canada, 2011). Similar to other suburban cities, the Town of Oakville is expected to see an increase of seniors over the next couple of decades. The Region estimates that the senior population will triple in size from 67,000 in 2011 to 187,000 by 2036 (Halton Region, 2013).

The Town of Oakville is experiencing an older population because the first Baby Boomer cohorts are over 65 years of age. Narrowing in on the age groups of seniors, Figure 3 shows the proportion of senior population in the Town of Oakville. The figure indicates that there has been an overall increase of seniors between 2001-2011 and more seniors appear to be living longer past 85 years of age (Statistics Canada, 2001, 2006, 2011). 


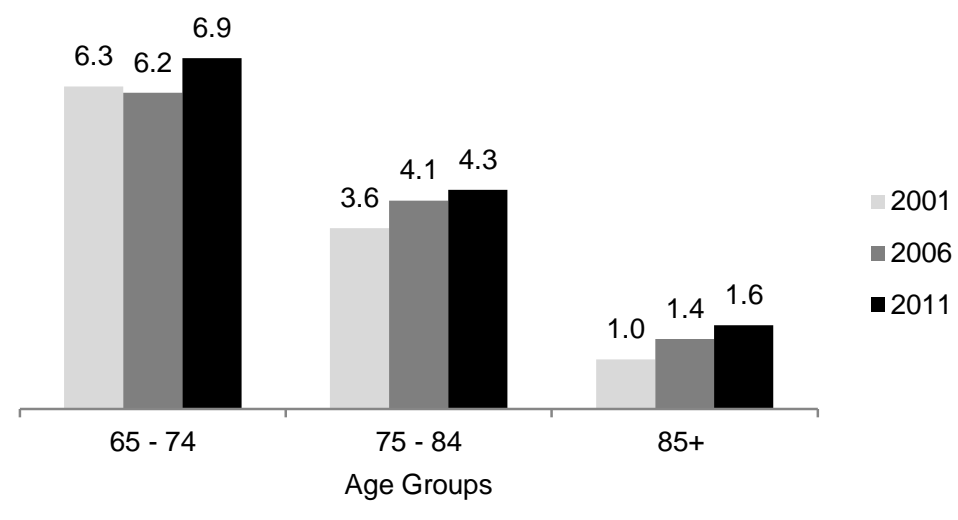

Figure 3: Comparison of Senior Population by Age Groups in the Town of Oakville (\%)

Source: Statistics Canada $(2001,2006,2011)$

There is a growing demand for public transportation service for seniors; Oakville Transit found that while the overall transportation ridership in 2012 increased by $3 \%$ from 2011, seniors transportation ridership increased by $25.9 \%$ (Oakville Transit, Budget Committee Report, 2012).

\subsection{Transit in Oakville}

Currently the cost for seniors to ride Oakville Transit public transportation is $\$ 3.50$ per ride, $\$ 18.00$ for a pack of ten tickets, $\$ 50$ for a monthly bus pass or $\$ 1.80$ per ride with a PRESTO ${ }^{3}$ card (Oakville Transit, 2014). The Official Plans of Halton Region and Town of Oakville include policies that strive for safe, efficient, accessible transportation systems that offer a realistic alternative to the private automobile. In line with these transportation policies and plans, the 13 week "Free Transit for Seniors" Pilot Program was launched beginning in July 2012 and experienced an increase of seniors taking the bus on the free day. The Pilot Program stipulated that any senior over the age of 65 was permitted to ride an Oakville Transit bus at no charge at any time on Mondays. The program became permanent pending on the annual budget.

This research will look at the effectiveness of this program to see how it has affected autodependence and transit ridership. Furthermore, this research will explore the perceptions of seniors towards the Ride for Free Public Transit Program and public transportation in general.

\footnotetext{
${ }^{3}$ Owned by Metrolinx, PRESTO is an electronic public transportation payment system that is available among 10 transit agencies, including Oakville Transit, in the Greater Toronto Area, Hamilton Area and Ottawa (PRESTO, 2014).
} 


\subsection{Survey Questionnaire}

The manager of the Town of Oakville's seniors' centres was contacted by e-mail in summer 2014 for permission to survey their membership. A total of four public seniors' centres offered to participate, but the researcher could only survey three given the time constraints. Participants were surveyed at three seniors' centres, managed by the Town of Oakville, during open houses in September 2014 (Table 3). In addition, a total of three seniors' centres and one senior residence were contacted and agreed for their membership and residents, respectively, to be surveyed in the common space. A total of 131 surveys were collected during the survey period (see Figure 4 for a map of the four locations that were surveyed and the location of participants by postal code or major street intersections $(n=104))$.

The researcher had a table set up during the open houses and encouraged community members to take part in the survey. The researcher was present to answer any questions that participants had about the study's goals, methods, and benefits.

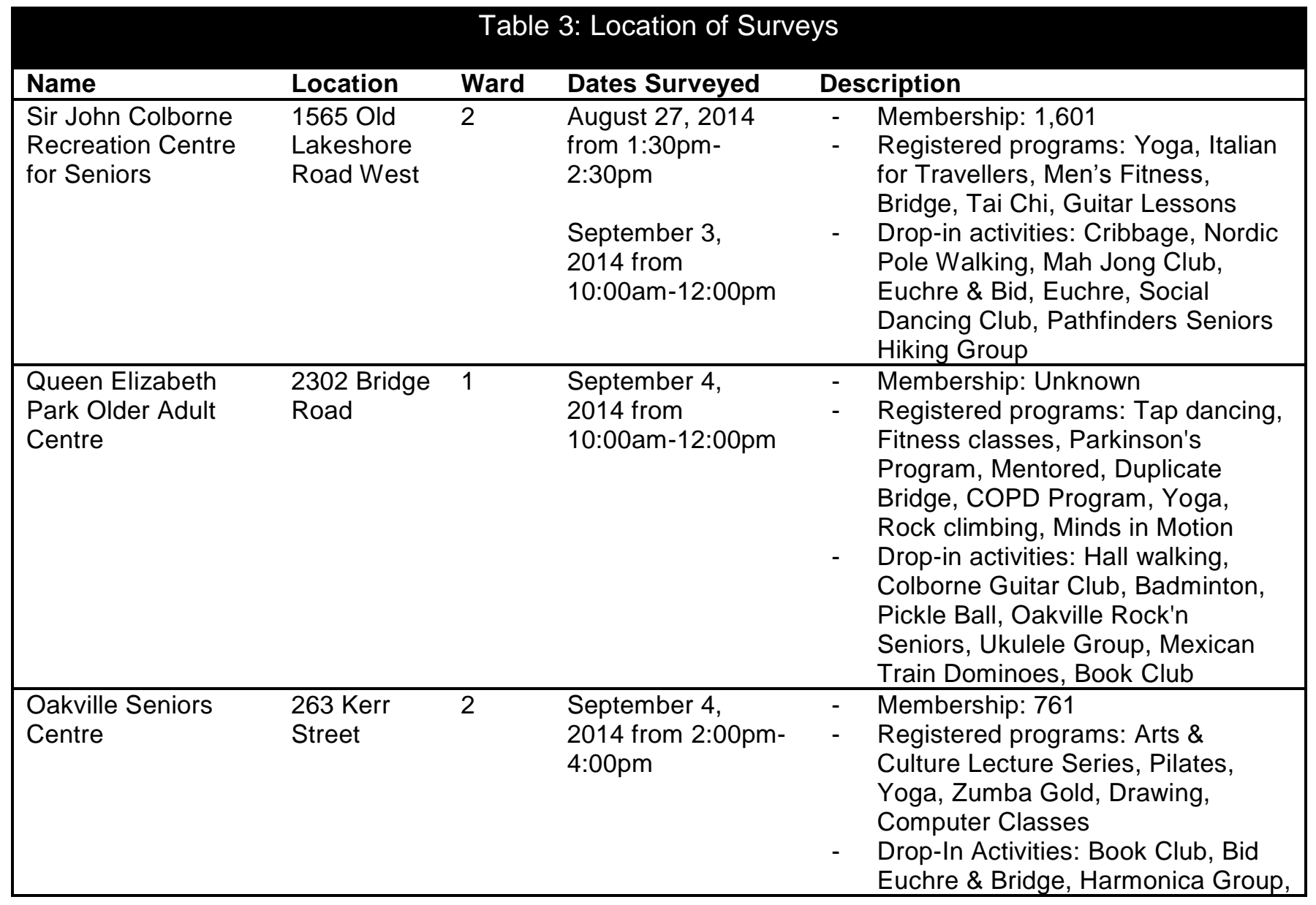




\begin{tabular}{|c|c|c|c|}
\hline & & & Carpet Bowling \\
\hline $\begin{array}{l}\text { John R. Rhodes } \\
\text { Seniors Residence } \\
\text { \& Neighborhood } \\
\text { Hub }\end{array}$ & 271 Kerr St 2 & $\begin{array}{l}\text { September 5, } 2014 \\
\text { from 9:00am- } \\
\text { 12:00pm }\end{array}$ & $\begin{array}{ll}- & \text { Apartment building: } 242 \text { units } \\
\text { - } & \text { Managed by the Halton Community } \\
\text { Housing Corporation } \\
\text { - } \quad \text { Offers senior assisted living } \\
\text { - } \quad \text { Close to amenities near the Kerr St. } \\
\text { area and the Kerr St. Seniors } \\
\text { Centre (Oakville Seniors Centre) }\end{array}$ \\
\hline
\end{tabular}

Source: Krever, 2010; Town of Oakville, 2014; Halton Region (n.d.)

With the permission of staff, a survey questionnaire was distributed to willing participants. Participants were asked questions on their frequency of travel using public transportation and private automobile, their reasons for taking and not taking public transit, and their perspectives towards the Ride for Free Transit Program on Mondays (see Appendix 1 for Survey). During the survey times indicated in Table 3, a total of 89 surveys were completed.

Upon the completion of the open houses, the researcher left three survey drop boxes at the Oakville Seniors Centre, Sir John Colborne Recreation Centre for Seniors and the John R. Rhodes Seniors Residence \& Neighborhood Hub Residence to collect more surveys. A drop box was not placed at Queen Elizabeth Park Older Adult Centre because the Town of Oakville staff felt that most of their membership had been at the Open House. The drop boxes were checked every two weeks from October to November 2014. A total of 41 surveys were collected from the drop boxes.

Furthermore, a community member with connections to $\underline{\mathrm{CARP}}$, an online platform for seniors to find community information, posted information about the researcher's project with a link to a survey and distributed this information on the list serve on October 31,2014. A total of one participant filled out the survey online. Figure 4 represents the home location of participants by postal code or by major street intersections and their proximity to Oakville Transit bus routes. 


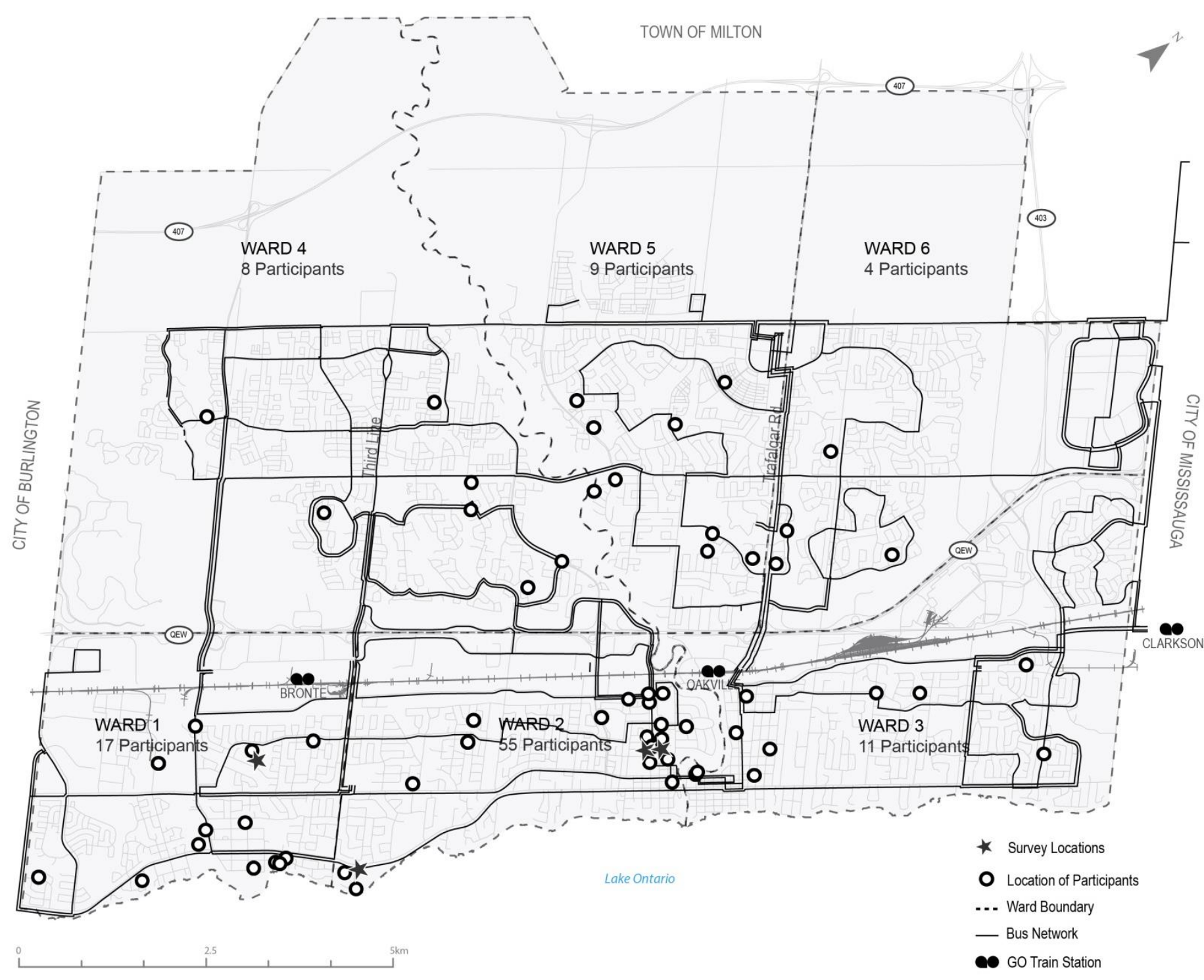

Figure 4: Location of Participants by Ward 


\subsection{In-depth Interviews}

During the survey, each participant was also asked if they would like to further participate in an in-depth interview. Among those who responded positively, 25 potential participants, who represented varying perspectives, behaviours and socio-demographic backgrounds, were approached to take part in an interview. A total of 16 participants consented to a semistructured in-depth interview, which were between 10 and 30 minutes in length (see Appendix 2 for Interview Guide). The researcher interviewed the majority of the participants in Oakville at the Oakville Seniors Centre with some interviews occurring on the phone through October and November 2014.

\subsection{Data Analysis}

The survey data was coded and entered into SPSS and stored on the researcher's personal computer. The analyses were descriptive in nature; key findings were selected from the survey were generated into tables and graphs to represent major patterns in data.

All interviews were audio recorded, transcribed verbatim, and the data was stored on the researcher's personal computer. Participants were given a pseudoname to preserve anonymity. The major themes of what participants perceptions towards driving, perceptions towards public transportation, their experience with the Ride for Free Transit Program and how the Program could be improved, were supported with key quotes in the analysis.

\subsection{Summary}

A questionnaire survey was conducted among participants at the Oakville seniors' centres Open Houses in September 2014. A total of 131 surveys were completed; and the data was then analyzed to understand current travel behaviour and the patterns of Ride for Free Transit Program use. Respondents who consented to an in-depth interview were contacted and 16 participants interviewed in-person and by phone. The data was transcribed verbatim and analyzed for major themes pertaining to participant's perceptions towards driving, public transportation, and experience with the Ride for Free Transit Program and how the program 
could be improved. The next two chapters delve into the survey and in-depth interview findings. 


\subsection{CHAPTER FOUR: THE EFFECTS OF THE RIDE FOR FREE TRANSIT PROGRAM ON SENIOR TRAVEL BEHAVIOUR}

This chapter focuses on the survey findings on senior travel behaviour, more specifically their frequency and access of driving and using public transportation. A total of 131 ( $n=131)$ participants completed a survey. Table 4 summarises the demographic profile of the sample. A large portion of the seniors were female (77.7\%). Most were aged between 75 and 84 years. More than half $(53.6 \%)$ of the seniors had attained post-secondary education. $34.4 \%$ of seniors reported their individual income was low ${ }^{4}$ (less than $\$ 40,000$ ), while $30.5 \%$ reported high incomes (\$40,000 or more). A majority of seniors indicated that they lived alone (57.3\%). Lastly, the large majority (82.4\%) of seniors spoke English at home.

\begin{tabular}{|lc|}
\hline \multicolumn{2}{|c|}{ Table 4: Demographic Characteristics of Survey Participants } \\
\hline Variable & SD (mean) \\
\hline Gender $(\mathrm{n}=121)$ & \\
Male & 22.3 \\
Female & 77.7 \\
\hline Age $(\mathrm{n}=123)$ & \\
65 to 74 & 34.1 \\
75 to 84 & 52.8 \\
$85+$ & 13.0 \\
\hline Years lived in the Town of Oakville $(\mathrm{n}=125)$ & \\
\hline Education attainment $(\mathrm{n}=125)$ & $16.7(29.6)$ \\
No High School & 1.6 \\
High School & 23.2 \\
Post-Secondary & 53.6 \\
Certificate & 10.4 \\
Trades & 2.4 \\
Other & 5.6 \\
Prefer Not to Say & 3.2 \\
\hline Individual income level $(\mathrm{n}=127)$ & \\
Low $($ less than $\$ 40,000)$ & 34.4 \\
High $(\$ 40,000$ or more $)$ & 30.5 \\
Prefer not to say & 35.1 \\
\hline Living arrangement $(\mathrm{n}=124)$ & \\
Live with partner & 36.3 \\
Live alone & 57.3 \\
Live with family & 4.8 \\
Other & 1.6 \\
\hline Language spoken at home $(\mathrm{n}=131)$ & 82.4 \\
English & 0.8 \\
French & 7.6 \\
Other & 9.2 \\
\hline Prefer not to say & \\
\hline
\end{tabular}

\footnotetext{
${ }^{4}$ Individual income categories were based on the individual median income levels of 2010 (CHASS, 2013). The median individual income in 2010 was $\$ 39,385$ based on National Household Survey data. Based on the median individual income, low income was defined as below $\$ 40,000$ and high income was defined as $\$ 40,000$ or more.
} 


\subsection{Travel Behaviour}

The results indicate that $67.8 \%$ of all seniors had access to a car as a driver and $60.3 \%$ of them had access to a car as a passenger. Moreover $43.5 \%$ of seniors reported that they used a car five or more days a week, while $17.7 \%$ said that they never used a personal vehicle (see Figure 5). In addition, 7.7\% reported that they used public transit five or more days a week, while $35.4 \%$ of seniors never used public transit (see Figure 6 ).

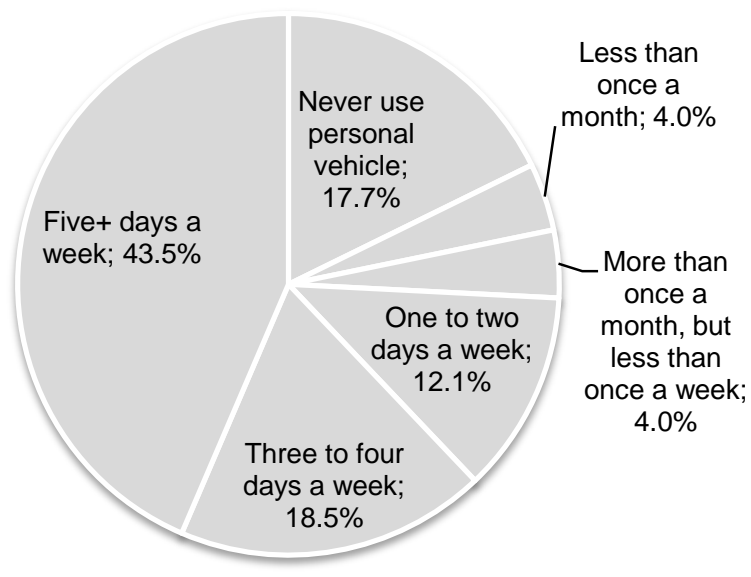

Figure 5: Frequency of Personal Vehicle Use $(n=124)$

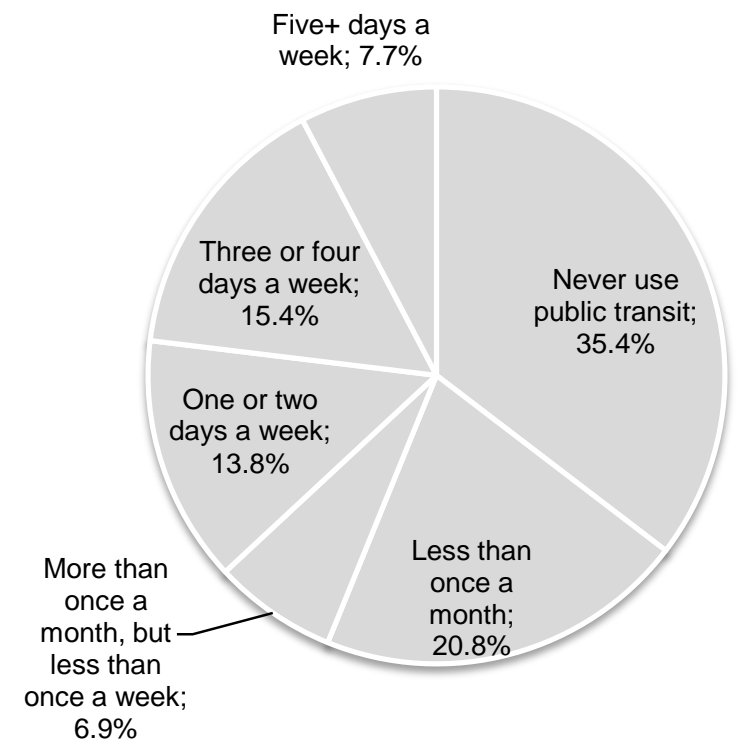

Figure 6: Frequency of Public Transportation Use $(n=130)$

Figure 7 highlights the reasons of using public transit. Many seniors stated that their main reason for taking public transit was because they preferred the independence of taking it by 
themselves. The other important reasons for using public transportation included that it helped to improve the environment and that it was more economical than driving. In addition $33.6 \%$ of respondents reported additional reasons for taking public transit, which included having no alternative transportation options $(9.2 \%)$, using the service to attend medical appointments or special events (4.6\%), traveling to the regional GO Train Stations (4.6\%), feeling safer and creating social connections during their ride $(6.9 \%)$.

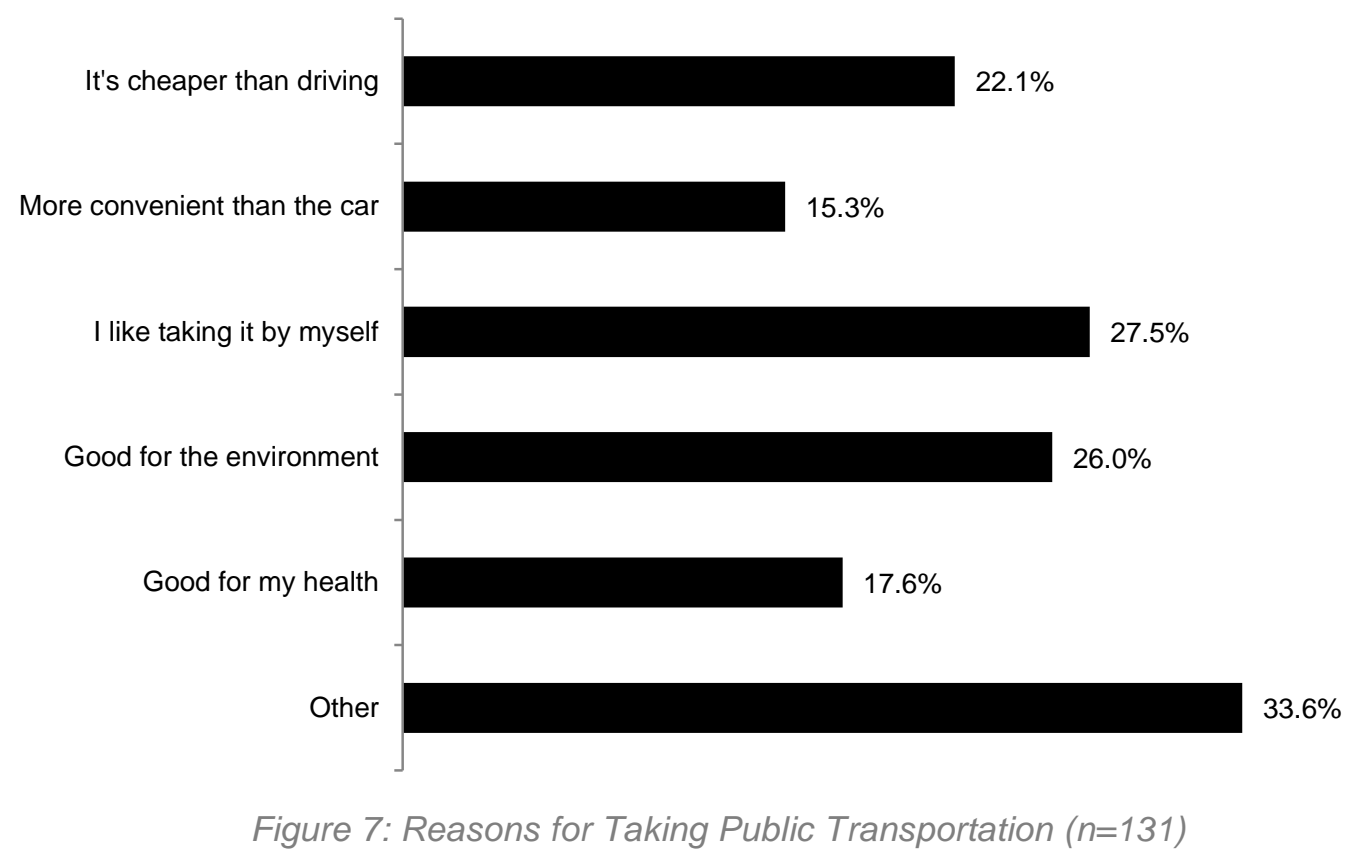

Conversely, Figure 8 summarises self-reported reasons for not taking public transit. The top reason was inconvenience. The next commonly selected answers were public transit was not accessible, it was too slow, and the fare was too expensive. In addition, $27.5 \%$ of seniors reported other reasons for not taking public transit, which included having access to a car $(14.5 \%)$, having personal or family medical reasons preventing them from using it $(3.8 \%)$, having a previous unpleasant experience $(1.5 \%)$, and lacking knowledge of how to use the system $(0.8 \%)$. 


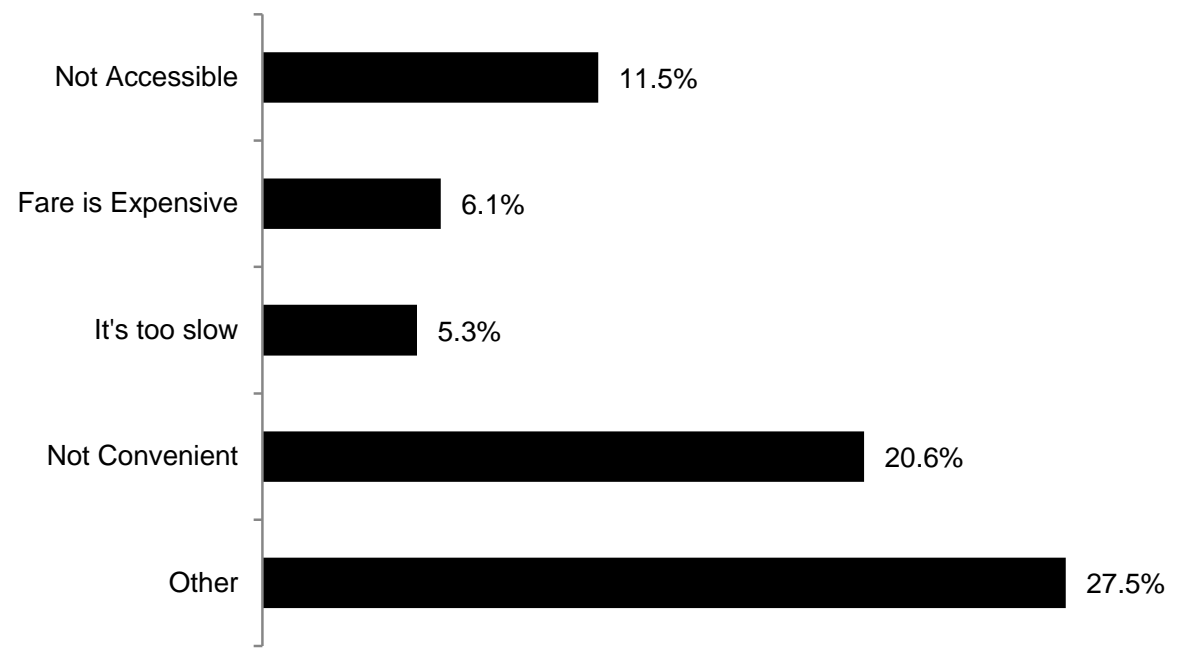

Figure 8: Reasons for Not Taking Public Transportation $(n=131)$

\subsection{Ride for Free Transit Program Use}

The survey also asked questions about seniors' perspectives on the Ride for Free Transit Program. The results indicated that $94.4 \%$ of seniors were aware of the Ride for Free Transit Program. Seniors were asked if they would be impacted if the Ride for Free Transit program service stopped. The results were mixed (Figure 9) with the majority of participants selecting neutral $(37.4 \%)$. When combined, more seniors $(38.3 \%)$ felt that the program would impact them if it stopped than those who did not feel this way (24.4\%).

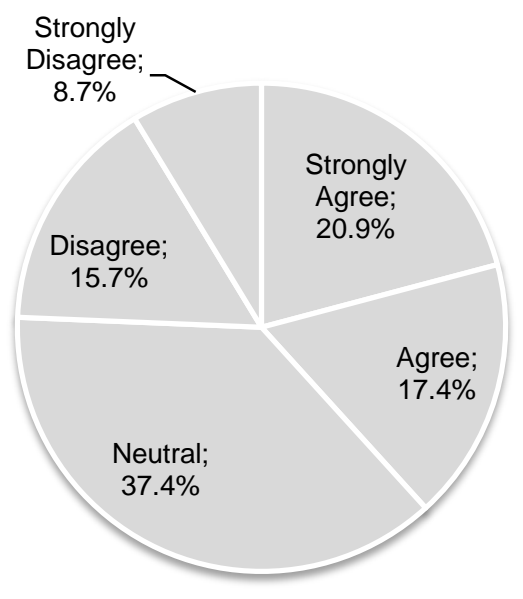

Figure 9: Impact on Participant if Program Stopped $(n=115)$

Next, focusing particularly on the changes in the public transportation use, seniors were asked if their public transportation use has increased or not changed after the Ride for Free Transit 
Program was implemented. Figure 10 shows that the program did not change the transit use for $63.1 \%$ of the majority of the participants, while it increased for $36.9 \%$ of those surveyed.

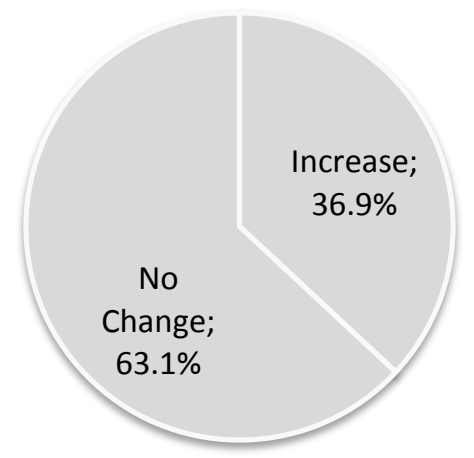

Figure 10: Ride for Free Transit Program Impact on Travel Behaviour $(n=111)$

Demographic variables of age, gender and income were further analyzed to see which ones affected the use of the Ride for Free Transit Program (see Table 5). This was completed in order to see if there were significant demographic differences within the Town of Oakville's senior population. $38 \%$ of females and $28 \%$ of males reported that they used public transit more. $44.4 \%$ of seniors between the ages of $75-84$ said that they used the program more. Compared to $22.9 \%$ of those with high incomes, $48.7 \%$ of those with low incomes were more likely to use transit. $72 \%$ of males, $75 \%$ of seniors aged $65-74$ and $77.1 \%$ of seniors with high incomes reported that the program had no impact on their travel behaviour. Using a chisquare test, it was found that the results were not statistically significant at $\alpha=0.1$ in the categories of gender or age. The results were significant between the low and high income groups.

\begin{tabular}{|lccc|}
\hline \multicolumn{4}{|c|}{ Table 5: Ride for Free Transit Program Impact on Travel Behaviour $(\mathrm{n}=111)$} \\
\hline & Use transit more $(\%)$ & No change $(\%)$ & Pearson Chi-square \\
\hline Gender & & & \\
$\quad$ Male & 28.0 & 72.0 & $0.953(\mathrm{df}=1)$ \\
Female & 38.8 & 61.3 & $\mathrm{p}=0.329$ \\
\hline Age & & & \\
65-74 years & 25.0 & 75.0 & $3.959(\mathrm{df}=2)$ \\
75-84 years & 44.4 & 55.6 & $\mathrm{p}=0.138$ \\
85+ years & 42.9 & 57.1 & \\
\hline Income & & & \\
Low $(<\$ 40,000)$ & 48.7 & 51.3 & $5.323(\mathrm{df}=1)$ \\
High $(\$ 40,000$ or more $)$ & 22.9 & 77.1 & $\mathrm{p}=0.021$ \\
\hline
\end{tabular}




\subsection{Summary}

The survey results indicate that the many seniors tend to favour driving in their car or being driven over taking public transportation. Seniors discussed many reasons why they would use public transportation, which included not having access to a car, taking public transportation by themselves, and saving money. Further, many seniors also stated reason why they would not take public transportation, which included that it was an inconvenience to their schedule and having access to a car. The Ride for Free Transit program does not appear to have a substantial impact on age and gender groups. The program had a significant impact on income levels. However, the results show that many seniors use public transportation on other days of the week (excluding Monday) and that they would consider taking public transportation more in the future. The following chapter delves into deeper understanding of how seniors perceive driving and public transportation. 


\subsection{CHAPTER FIVE: SENIORS' PERSPECTIVES ON PUBLIC TRANSPORTATION}

Chapter 4 explored travel behaviour through surveys and this chapter highlights seniors' opinions towards automobile and public transportation use. The key findings from the literature review of seniors' perspectives towards public transit were that seniors viewed the service positively in their daily schedule or negatively as a last resort travel option. The interviews explored this topic further and provided additional insight into why a senior may like or dislike driving and why they may like or dislike taking public transit. In addition, using the interview data, rider experiences about the Ride for Free Transit Program was documented. Lastly, interviewees commented on how the Town could improve public transit in general and the Ride for Free Transit program to increase transit ridership.

Table 6 summarizes the profiles of those who were interviewed. The participants were predominately female and were in the age range of 65 to 74, which was a younger group in comparison to the survey results. Most of the participants had completed post-secondary education. Many participants reported low individual income levels and lived alone. English was the primary language spoken at home. 


\begin{tabular}{|c|c|c|c|c|c|c|c|c|c|c|c|c|}
\hline Participant & $\begin{array}{l}\text { Access to } \\
\text { Car }\end{array}$ & $\begin{array}{l}\text { Car Use per } \\
\text { week }\end{array}$ & $\begin{array}{l}\text { Transit use per } \\
\text { week }\end{array}$ & $\begin{array}{l}\text { Aware of } \\
\text { Ride for } \\
\text { Free } \\
\text { Program }\end{array}$ & $\begin{array}{l}\text { Program } \\
\text { impact on } \\
\text { my transit } \\
\text { use }\end{array}$ & $\begin{array}{l}\text { I would be } \\
\text { impacted if the } \\
\text { Program } \\
\text { stopped }\end{array}$ & Gender & Age & Education & Income & Living Situation & Language \\
\hline Sandra & Yes & $5+$ days a week & Never use & Yes & No change & Disagree & Female & 65 to 74 & Post-Secondary & High & Live with family & English \\
\hline Rachel & Yes & $5+$ days a week & $\begin{array}{l}>\text { once a month, } \\
\text { but }<\text { once a week }\end{array}$ & Yes & Increase & Neutral & Female & 65 to 74 & High School & High & Other & English \\
\hline Ellen & Yes & $\begin{array}{l}>\text { once a month, } \\
\text { but }<\text { once a } \\
\text { week }\end{array}$ & 1 to 2 days a week & Yes & Increase & Strongly Agree & Female & $85+$ & Post-Secondary & Low & Live alone & English \\
\hline Douglas & Yes & $5+$ days a week & $<$ once a month & Yes & No change & Neutral & Male & 75 to 84 & High School & Low & Live alone & English \\
\hline Joshua & Yes & $5+$ days a week & $<$ once a month & Yes & No change & Disagree & Male & 65 to 74 & Post-Secondary & $\begin{array}{l}\text { Prefer not } \\
\text { to say }\end{array}$ & Live alone & English \\
\hline Nadia & No & Never use & $5+$ days a week & Yes & No change & Neutral & Female & 75 to 84 & Post-Secondary & High & $\begin{array}{l}\text { Live with } \\
\text { partner }\end{array}$ & English \\
\hline Randolph & Yes & $5+$ days a week & Never use & Yes & No change & $\begin{array}{l}\text { Strongly } \\
\text { Disagree }\end{array}$ & Male & 65 to 74 & Post-Secondary & High & $\begin{array}{l}\text { Live with } \\
\text { partner }\end{array}$ & English \\
\hline Diane & Yes & $5+$ days a week & Never use & Yes & No change & Neutral & Female & 65 to 74 & Certificate & $\begin{array}{l}\text { Prefer not } \\
\text { to say }\end{array}$ & $\begin{array}{l}\text { Live with } \\
\text { partner }\end{array}$ & English \\
\hline Amy & Yes & $5+$ days a week & 1 to 2 days a week & Yes & Increase & Disagree & Female & 75 to 84 & Certificate & $\begin{array}{l}\text { Prefer not } \\
\text { to say }\end{array}$ & Live alone & English \\
\hline Ella & No & Never use & < once a month & Yes & No change & Neutral & Female & $85+$ & Post-Secondary & Low & Live alone & English \\
\hline Theresa & Yes & $\begin{array}{l}3 \text { to } 4 \text { days a } \\
\text { week }\end{array}$ & 3 to 4 days a week & Yes & Increase & Strongly Agree & Female & 75 to 84 & Post-Secondary & Low & Live alone & English \\
\hline Mary & Yes & $5+$ days a week & $<$ once a month & Yes & $\begin{array}{l}\text { Prefer not to } \\
\text { say }\end{array}$ & Neutral & Female & $\begin{array}{l}\text { Prefer not } \\
\text { to say }\end{array}$ & Post-Secondary & $\begin{array}{l}\text { Prefer not } \\
\text { to say }\end{array}$ & Live alone & Other \\
\hline Todd & Yes & $\begin{array}{l}1 \text { to } 2 \text { days a } \\
\text { week }\end{array}$ & $5+$ days a week & Yes & Increase & Strongly Agree & Male & 65 to 74 & Post-Secondary & Low & Live alone & English \\
\hline Brenda & Yes & $\begin{array}{l}1 \text { to } 2 \text { days a } \\
\text { week }\end{array}$ & Never use & Yes & No change & Disagree & Female & 65 to 74 & Post-Secondary & High & Live alone & English \\
\hline Fran & No & Never use & 3 to 4 days a week & Yes & No change & Strongly Agree & Female & 75 to 84 & Post-Secondary & Low & Live alone & Other \\
\hline Ralene & No & Never use & $5+$ days a week & Yes & No change & Neutral & Female & 75 to 84 & Post-Secondary & Low & Live alone & $\begin{array}{l}\text { Prefer not } \\
\text { to say }\end{array}$ \\
\hline
\end{tabular}




\subsection{Perceptions of Driving}

If a participant drove, they were asked what they liked about it. It was found that participants liked driving because they perceived to be in more control of their schedule, it was more convenient by saving time from commuting, and that it was an easier way to get directly to destinations. Participants were also asked what they disliked about driving and it was found that driving became stressful once their physical health declined.

One example was Josh who was semi-retired, but was still actively involved in the community through volunteering and participation in community organizations. He reported driving more than five times a week. He viewed driving as a tool to leverage his independence:

Well, it gives me freedom. You know, it's not structured to a time. It's because l'm physically able to do it. (Josh, 65-74 years).

Another participant, Randolph, who drove more than five times a week and vacationed to Florida in the winter, expressed his preference for driving because it was faster than public transportation:

I know this sounds rather funny, but I do enjoy driving in my vehicle. For example, I go to the [YMCA], which is almost on the other side of town to me. It would take me half a day to get there and back [using the bus]. I can be there in 15 mins. (Randolph, 65-74 years)

Another theme highlighted by Rachel, who also drove more than five times a week, was that driving seemed to be easier to use than transferring on public transportation:

I guess I don't have to worry about the weather so much. You know, waiting at the bus stop and so on. [...] So it's just getting from point $A$ to $B$ without the hassle of changing buses and so one so forth. I used to have to drive in my job, so I'm comfortable with it. (Rachel, 65-74 years)

In contrast, participants noted that their preference for driving diminished with their decline in health because they needed to be more alert and focused on their surroundings. Many participants viewed driving as an activity that carried a lot of risk such as getting into an accident. Brenda, who drove one to two days a week, commented on the physical difficulty of driving of staying alert and her vision declining as she became older: 
I think the older I'm getting, I'm finding that I have to pay more attention. Um, and I'm always worried... I notice that a lot of people go through red lights now and yellow lights. And it's bothersome to me. [...] I don't like driving at night because again it's my vision - it's not as good as it was; it's not as sharp. (Brenda, 65-74 years)

\subsection{Perceptions of Public Transportation}

Having public transportation service appeared to be an important option for seniors who have stopped driving their cars or who were starting to use their car less. Participants were asked what they liked about taking public transportation. Some respondents discussed themes of independence, social interaction, friendly Oakville Transit bus drivers, and exploring their neighbourhood as a benefit of having bus service. When asked what participants disliked about public transportation, many described the service as inconvenient with a lot of time allocated to waiting for the bus or transferring, they also highlighted the barrier of inclement weather, and lastly, the barrier of learning how to use the system.

Douglas, who drove his car more than five times a week and used the bus less once a month, commented on the utility of having public transportation as keeping seniors independent and alleviating anxiety that their daily activities are a burden on someone else's schedule:

Well, if you can't drive anymore and there's someone to drive you then you sort of feel obligated. You know, you go to the Doctor's or the grocery store, it may take you five minutes longer than you expected and then you think, oh [the person who drove me is] waiting for me. I better go. And with public transit [...] if you had to pay a second ticket or whatever, it's not all that much money. And it relieves you that way. (Douglas, 75-84 years)

Another perceived benefit of taking public transportation was the social connections that were forged through unexpected interactions when taking the bus. Amy, who drives her car five or more times a week and takes the bus less than once a month, discussed how she used the bus service to socialize with people on the bus:

Lots of time I have people to talk to when you're standing there [at the bus stop] you get into conversations [with people]. [...] You just strike up a conversation and you get to know a lot of stuff that you wouldn't have known other words. (Amy, 75-84 years).

The friendliness and politeness of Oakville Transit's bus drivers was a strong theme that many participants acknowledged. Ralene, who did not have access to a personal vehicle and used 
Oakville Transit five times a week, lamented on the positive impact that Oakville Transit bus drivers had on seniors' commutes:

And I will tell you one thing, the bus drivers are absolutely wonderful. Whether they are male or female, they are extremely polite. They are nice and helpful. (Ralene, 75-84 years).

As an avid bus user who has a SPLIT pass, which is available to Halton Region residents below a certain income, Ralene also discussed leveraging public transportation as a way to explore her neighbourhood:

Well, I find that if I am bored I can take the bus and go to an area right to the end of the trip and come back on the same bus. Just for a visit in that area because otherwise I wouldn't. And I don't have to get lost. (Ralene, 75-84 years).

Seniors such as Ellen, who drove more than once a month and take the bus one or two times a week, appreciated having the public transit service so that she could expand her daily activities to other areas of Oakville not accessible on foot.

Well, I have begun to use it more because l've exhausted all the possibilities within my walking area. And I want to go further. Ellen (85+ years).

On the other hand, there were many reasons as to why people did not like taking the bus, which reflects their perspectives towards public transportation. These themes included that the bus was inconvenient, if there was inclement weather or if they lacked understanding of how to use the system.

Randolph described his reason for not using the bus as an inconvenience because the time it took to wait for the bus, transfer between buses, and finally get to his destination could not match the speed or ease of a car:

I'd have to walk down the street and find the bus stop, which I don't know where it really is. And then l'd have to wait for the bus. l'd have to wait for it to stop all along to where I was going and then transfer once and twice. So to me that's just not very convenient. (Randolph, 65-74 years)

Several participants noted that inclement weather during the winter was a major barrier to taking public transportation. Theresa, who drove her car and used the bus both three to four times a week, said that a reason for not taking public transportation would be inclement 
weather such as snow coupled with the lack of maintenance, which made getting on and off the bus a barrier:

Because sometimes if it's snowing the banks are so high you can hardly get on and off the bus and that's one of the things that we have a lot of beef about. I don't know if it's public transit or works who cleans. (Theresa, 75-84 years).

Those who did not use transit discussed their lack of knowledge about the public transportation system in Oakville. While Brenda typically drove her car one to two times a week, she was unfamiliar with the system and therefore did not know how to navigate her way through it:

Well, you know, because I don't really use [public transportation] and I don't know anything about the routes, I don't know where if I wanted to go downtown how I could get there. I don't even know where l'd call, I guess l'd call or go on the computer. (Brenda, 65-74 years).

\subsection{Experience with the Ride for Free Transit Program}

Seniors acknowledged that the Ride for Free Transit Program could save them money, but few participants seemed to heavily rely on the program. For those who did not regularly use the bus, it appeared that they took advantage of the program when they had to a medical appointment and did not want to pay for parking. For some who regularly used the bus, they had a SPLIT pass and said that it was about $\$ 10 /$ month $^{5}$. This was a more convenient option than using the Ride for Free Transit Program available only on Mondays because riders could use the bus at any time. Further, it was a more economical option for bus riders that used the bus on days other than Mondays because their subsidized bus pass would cover their fare.

Todd, who drove one to two days a week and took the bus more than five times a week, said that the program was helpful to save money because seniors are on fixed incomes:

You know, and when you're a senior, you're on a fixed income. So any way you save money is helpful. It's a benefit. (Todd, 65-74 years)

Sandra, who drove five times a week and never used public transit, primarily took care of her grandchildren during the day. She commented that the program would not be beneficial for her schedule and would not financially impact her:

\footnotetext{
${ }^{5}$ The price of an individual's bus pass is determined on a case by case basis (Halton Region, n.d.).
} 
I would not use [the program], unless I had to go to the hospital on Monday or something, but otherwise I do too many things to be bothered about thinking one day a week. [...] Money is not that much of a concern for me. It is for some people l'm sure, but it's not a big saving and it's certainly not a big convenience at one day a week. (Sandra, 65-74 years).

Ralene lived in Downtown Oakville and frequently goes to Hopedale Mall or to visit the Bronte area. She used to use the Ride for Free Transit program, but does not rely on it now that she has a SPLIT pass allowing unlimited travel during the month.

I never used to have the SPLIT pass. But since I have the SPLIT pass, I use it just as often. [The program] doesn't affect me. Other people, other people I know. It's wonderful for them. And as a matter of a fact, I meet them on the bus because of [the Ride for Free Transit Program]. (Ralene, 75-84 years).

\subsection{Improving the Ride for Free Transit Program}

When asked what Oakville Transportation could do to better improve the Ride for Free Transit Program, participants commented on increased education on how to use the service and how to transfer between buses, an increase in the number of free days in a week, increased maintenance of clearing snow and ice around bus stops and the connections to them, increased promotion of the Ride for Free Transit Program, increased coordination between businesses and the program to incentivize seniors, and some participants felt that the program was satisfactory and did not require improvements.

Rachel primarily used the bus to go to the mall, but she described being uncomfortable if she had to transfer between buses:

I think that [Oakville Transit is] doing a good job. Now, as I say I kind of just get on [the bus] and go to here. But if I had to transfer like if I had to go to the North end of town and transfer two or three times that might be different. But I don't really know that at this point. So I don't really... other than the one time, l've never really used the transfer system, so I don't know. (Rachel, 65-74 years).

Similarly, Nadia, who was highly independent, discussed more education of the service through an orientation that could inform people how to use public transportation because there seemed to be a perceived fear of knowing where the bus goes. 
They [other seniors] don't know where the bus goes and where it stops. It's not like they've not been on a bus, but it's just they don't know where it goes. So the only helpful thing I would say on there is if they could have some sort of orientation meeting for these people and maybe go to a senior centre or apartment and just have a meeting with them and maybe even just take them. (Nadia, 75-84 years).

An interesting theme that Josh discussed was better collaboration between businesses and Oakville Transit to create senior discounts on other days of the week, which could increase economic activity in the Town.

I think the benefit is if it [the program] was expanded should spill over to the business and those types of... or get all the businesses to do their senior discount days on Mondays, which is not practical. [...]. But, you know, for a certain segment of the population to create more activity. (Josh, 65-74 years).

\subsection{Summary}

This chapter explored the senior perceptions of driving and using public transportation and what participants liked and disliked about each mode. The participants interviewed had varying schedules and accessibility to travel options. It was found that most participants prefer to drive to save time, while participants use the bus to avoid unsafe driving conditions due to their declining health or to explore their neighbourhood and foster social connections with people they meet when taking the bus. Participants who had a SPLIT pass or monthly bus pass did not use the Ride for Free Transit Program because they could use transportation at any time during the week. A major barrier to seniors using the public transportation or the Ride for Free Transit Program was that they did not understand where buses went on their routes or how to transfer between buses. Some participants suggested that there needs to be more educational awareness and an orientation to physically show people how to use the service. When asked about how participants would be impacted if the Program was discontinued, there were some seniors who felt that they would be affected financially or who suggested they would not be able to go out because they relied on the Ride for Free Transit Program to get around. 


\subsection{CHAPTER SIX: DISCUSSION}

The participants in this study were over the age of 65 and had varying travel behaviour frequencies and perspectives towards public transportation and the Ride for Free Transit Program. Data was collected through surveys and interviews. Most of the findings were consistent with what was found in previous studies focused on travel behaviour among seniors. However, there is a paucity of research completed on the Ride for Free Transit Programs especially in suburban municipalities, making it difficult to support or contrast some of the findings found in this case study.

The survey results suggest that most seniors drive to participate in day-to-day activities and only a small proportion take transit. More precisely, the survey found that most seniors in Oakville relied on the automobile as their main mode of transportation with $43.5 \%$ of seniors stating that they used the car at least five times or more a week and $34.5 \%$ of seniors stating that they never used public transportation. The pattern is similar to what has been reported in other studies (such as Rosenbloom, 2001; Alsnih \& Hensher, 2003; Páez et al., 2007). A high percentage of seniors $(67.8 \%$ ) had access to a car as a driver, and $60.3 \%$ had access to a car as a passenger. Furthermore in the interviews, many participants stated that they chose driving because they enjoyed it and because it was easy to use. Although the survey did not ask seniors specifically about their daily activities, many of the interview respondents reported having fairly active lifestyles throughout the week that required the use of a car to take care of their families, to attend exercise classes or community clubs, or to run errands. This active lifestyle of seniors is similar to the studies done by Alsnih and Hensher (2003) and Hensher (2007).

This study builds on the findings from the Oakville Free Rides for Seniors Transit Pilot Program (Oakville Transit, Budget Committee Report, 2012). The Pilot survey focused on free transportation use. In contrast, the findings from this MRP research provide insight into how the program has affected travel behaviour among seniors and what the perspectives of seniors are towards the Program. The findings from the survey are also consistent with the results from the Town of Oakville's Pilot Program Survey in the aspect that few seniors identified themselves as avid bus riders. Also with regard to the reasons for public transit use, the findings in this study were somewhat similar to the Pilot Program survey, which found that seniors commonly used the free bus service to go to the hospital for medical appointments, go shopping, or to attend special events (see discussion for Figure 7). 
The survey results showed that income was a significant factor in determining if a senior was influenced by the Ride for Free Transit Program. Some interviewees discussed the importance of saving money because they were on a fixed income. In addition to the Ride for Free Transit Program, many low income seniors reported using the SPLIT program. This meant that some seniors with low incomes benefitted from the Ride for Free Transit Program and the SPLIT program, but they did not have to rely on the Ride for Free Transit Program.

It is then clear that the Ride for Free Transit program does not specifically attract low income seniors who are using a SPLIT pass. Instead, the program can benefit all income groups, but those who earn less than $\$ 40,000$ use the Program more. Interview respondents also said that they would consider using public transit more when their health declined or when they had decreased access to a car. The vast majority of seniors surveyed knew about the program $(94.4 \%)$, but the impact of taking away the program had mixed results $(37.4 \%$ selected neutral, $38.3 \%$ felt they would be affected, and $24.4 \%$ mentioned that they would not be impacted). Previous studies have reported that public transportation became more important as the health of a senior or the ability to drive decreased (Smith \& Hiltner, 1988; Newbold et al., 2005; Michael et al., 2006; Hodge, 2008; Coronini-Cronberg et al., 2012; Kerr et al., 2012). Our exploration in Oakville revealed similar results; seniors felt that the program would be beneficial when they stopped driving in the future. Some seniors disliked driving because as they got older they had to concentrate more when they drove and experienced declining vision.

The survey findings showed that the majority of participants' $(63.1 \%)$ travel behaviour had not changed since the inception of the Ride for Free Transit Program (see Figure 10). Since many seniors' travel behaviour did not change from the Ride for Free Transit Program, it could indicate that one of the reasons is because many had access to a car, which CroniniCronberg et al. (2012) described as the main reason for determining transportation choices.

The most popular option selected for taking public transportation (27.5\%) in the survey was that participants liked being able to take it by themselves. An interview respondent discussed the relief of being able to go grocery shopping by taking the bus without being on someone else's schedule. This implies that some seniors valued their freedom and disliked relying on social networks for rides. Many studies suggest that independent mobility is vital in sustaining 
a senior's dignity because they would not feel like a burden when asking friends, family, or community members for rides (Rosenbloom, 2001; Hodge, 2008, Frank et al., 2013).

Previous research has pointed out that conventional public transportation systems with fixed routes and schedules are not conducive to the lifestyles of today's seniors (Alsnih \& Hensher, 2003; Hensher, 2007; Páez et al., 2007; Scott et al., 2009; Kim, 2011). Similar results were observed in Oakville. An interview respondent felt that taking public transportation during their day would be time consuming because it would result in long commute times on a fixed route, and time spent waiting for the bus. Another respondent discussed that driving was more straightforward between destinations than taking the bus.

Another theme that emerged from the interviews was that seniors were less likely to take public transportation when there was inclement weather. Novek and Menec (2014) discussed the importance of seniors depending on the bus during the winter, but sidewalks were found to be "not walkable, slippery, [and] dangerous" (p. 1066). Rittner's (1995) study also found that personal safety, unwelcoming environments, and difficulty with physical access to the bus provided negative perceptions of taking public transportation.

Another key finding was that the Ride for Free Transit Program was an opportunity for seniors to explore their neighbourhood and to meet others. Some seniors reported that they would take public transportation because it allowed them to go on an adventure or meet people at bus stops highlighting the positive social benefits. The finding was consistent with the existing literature that showed that public transportation can help connect seniors with others (Michael et al., 2006) and help increase public transportation use (Richard et al., 2009). These soft benefits were mentioned anecdotally in the Pilot Program survey that was conducted in 2012 (Town of Oakville, Budget Report, 2012). This research has provided a baseline of quantifying a percentage of seniors who reported other positive benefits of the Ride for Free Transit Program.

One recommendation discussed in the interviews to improve the public transportation system in Oakville was to provide inexperienced seniors with demonstrations and educational workshops on how to use the bus. Some seniors suggested having public transportation orientations that could be done at community centres. This could help seniors understand how to navigate the public transportation system and make taking the Ride for Free Transit 
Program more user-friendly. Another recommendation was how the program could be better incorporated with local businesses to further incentivize seniors to use public transportation to receive a shopping deal. The Ride for Free Program is currently offered on Mondays, but could work more with local businesses and Business Improvement Areas to provide seniors with a discount at a shop or restaurant for taking the bus. This could encourage seniors to spend more money and support local business, while increasing their transit ridership.

\subsection{Policy Implications}

The influx of seniors in the decades to come will play an important role in developing transportation policies and programs that reflect the needs of this large and diverse population and providing adequate transportation services for seniors will be placed on municipalities. Integrating senior transportation policies will help to include seniors into the conversation and help cities transform into more age friendly and inclusive places. The benefits of a mobile and independent senior population may improve their physical and mental well-being.

This research evaluated the impact the Ride for Free Transit Program had on senior travel behaviour. The survey results indicated an increase $37 \%$ of seniors used public transportation because of the Ride for Free Transit Program. This evidence supports that this type of alternative transportation program is beneficial for some segments of the senior population. Namely, the program was found to be significant across low and high incomes, but not for gender or age. The Ride for Free Transit Program could present an opportunity for seniors transitioning from driving private automobiles to taking public transportation. The Town of Oakville's transportation policies should strive to offer a variety of programs that will benefit different types of seniors.

To enable the transition of seniors who would like to take the bus, the Town of Oakville should consider better education around public transportation. Many seniors reported a lack of knowledge of where the bus went, how to transfer between buses, where bus stops were, and how to navigate public transportation maps and schedules. Re-working these concerns by providing an educational workshop at community centres could increase end user benefits.

Oakville's senior population tends to have active lifestyles within the community. The traditional fixed bus routes, fixed scheduling and short transfer time is not conducive to today's senior. The Town of Oakville could explore a demand responsive transit system, 
which uses flexible bus routes and schedules that is a cross between a public transportation system and taxi (Transportation Systems Center, 1974). These types of systems can be more flexible and convenient for passengers by offering a direct route to destinations (Transportation Systems Center, 1974). While these systems can be more convenient, the cost of these types of systems can be more expensive than traditional public transportation systems, therefore the feasibility of this system should be further investigated. The Town of Oakville should consider increasing the two hour transfer time in a single trip as some seniors expressed difficulty with completing their activities in the current transfer period. Seeing as the bus frequency on weekends is once every hour, a two hour transfer period on weekend should be increased to accommodate the needs of seniors. Furthermore, inclement weather in the winter was a major barrier to seniors taking public transportation. Improved access to bus stops will need to improved coordination with the Town of Oakville, property owners and third parties to ensure that sidewalks are properly cleared.

\subsection{Limitations of Data}

This study studied a particular senior population at one point in time. A longitudinal research that would study the same population over a period of time, such as before and after a Ride for Free Transit Program is implemented, could not be conducted. A longitudinal study would help to compare baseline data with "after-implementation" data in order to better analyze the changing public transportation needs of seniors, which might inform policies and programs more effectively (Flvberg, 2011).

Given the limited time for this research, smaller samples for the surveys $(n=131)$ and the interviews ( $n=16)$ had to be relied on. However, it could be argued that the seniors that use the Ride for Free transit program are a specific sub-population, which would deem the survey sample size sufficient. The sample size that was used in this study was also comparable to other similar works. For example, a study by Franke et al. (2013) looked at the physical activity in low-income older adults on rent subsidies and used data from 161 questionnaires and 17 qualitative interviews.

Since this research was undertaken in the timeframe of an MRP, the survey questions could not be piloted beforehand. The survey question that asks about individual income could have included different category breakdowns that would include a low income bracket of less than 
$\$ 30,000$ based on the Halton Health Line (MississaugaHaltonHealthLine, 2015), medium income bracket of $\$ 30,000$ to $\$ 60,000$, and a high income bracket of more than $\$ 60,000$. The category breakdown of individual income categories was based on the individual median income of Oakville using National Household Survey (NHS) data in 2010. The reliability of 2011 NHS data must be cautioned as this dataset is voluntary and less accurate than its comprehensive long-form predecessors. The Global Non-Response Rate in Oakville was acceptable at $21.5 \%$ because it was below the $50 \%$, which is the threshold for low data quality. Further, another question that could have been improved with a pilot survey was why seniors take public transportation. Since many participants wrote that they did not have access to a car, the options should have included "no longer having access to car" or "not knowing how to drive," which would have improved the accuracy of the survey results.

With regard to reliability of the responses, a total of 89 surveys were administered in person during open houses at the community centres and in the common space of the senior residence. The rest of the survey participants $(n=42)$ completed surveys by themselves and submitted them in the drop box or online; they did not have the benefit of consulting with the researcher for any questions or clarifications, which may have affected the quality or reliability of their responses.

In addition, many of the participants were surveyed at the Town of Oakville Senior community centres and a Senior citizen residence, which were located closer to the downtown core of Oakville. This research also acknowledges that many seniors do not live in senior residences or use senior community centres such as new immigrants, thus a large segment of the senior population may not have been reached. Oakville Senior Services stated that one third of Oakville's senior population (based on Statistics Canada data from 2006) was comprised of new immigrants. The participation of new immigrants was not reflective of the total population because new immigrants only account for $5 \%$ of the community centre membership (Krever, 2010).

Despite some limitations, this study makes a significant contribution in understanding the impact of Ride for Free Transit Programs on senior travel behaviour. This case study will add to a growing body of literature on Canadian senior perspectives towards free public transportation in suburban municipalities. 


\subsection{CHAPTER SEVEN: CONCLUSION}

Understanding the specific transportation needs of seniors will have implications for planners and policy makers. Public transportation may become more popular in suburban municipalities if policies and programs can accommodate the influx of trips that seniors take. Studies on public health, senior travel behaviour, and senior perspectives on public transportation have been more descriptive with their findings, but quantifying senior travel behaviour on public transportation has been scarce.

This case study on Oakville, Ontario was conducted to examine the effects of the Ride for Free Transit Program. Overall, it was found that the Program did not change travel behaviour for $63 \%$ of seniors, but it increased public transportation ridership for $37 \%$ of seniors. The travel behaviour of Oakville's seniors was similar to findings found in other studies, where more seniors drive than ever before, but tend to take public transportation less. Another factor that could affect senior ridership was that since some seniors were eligible for the SPLIT program, they did not need to rely on the Ride for Free Transit Program. However, the results showed that income was a significant factor for seniors using the Ride for Free Transit Program. This could suggest that those who earned less than $\$ 40,000$ used the Ride for Free Transit Program more than those who earned $\$ 40,000$ or more. Within interviews, participants felt that they would use the Ride for Free Program if they experienced health decline or no longer had access to a car.

Understanding the travel behaviour and perspectives towards public transportation of seniors in Oakville could be useful in gauging the travel needs of seniors over time. Many seniors perceived public transportation to be inconvenient as the routes and scheduling were fixed, and to be a slow mode of transportation compared to the car. Seniors also discussed themes of personal safety pertaining to the weather when accessing public transportation by bus stops because of winter snow conditions. More positively, some seniors also perceived the bus to be an enjoyable service, a great option since their health declined, more economical than driving and owning a car, an opportunity to build social relationships and connect to the community, and allow the option to take public transportation by themselves.

The intent of this research is not to convert all seniors into taking public transportation, but rather, it underscores the importance of transportation alternatives for seniors. This information may be useful for policies that look at programs that adopt free ride aspects. It is 
important to select free ride programs that will not only provide the best service for the cost, but will also have many positive benefits for seniors even if they are harder to quantify.

Further research on this topic could look at quantifying the number of trips and time spent commuting by car and by bus, which could provide more specific data on senior travel behaviour and set a baseline of information on how much intervention programs could affect senior travel behaviour. More research could also look at the spatial patterns of seniors' activities and how public transportation routes could be readapted to make them more useful. Further research on Ride for Free Transit Programs could look at measuring the positive benefits of social interaction seniors receive along bus routes or at bus stops. Lastly, other municipalities considering a similar program could conduct a study before the implementation and after to evaluate the effectiveness of the program on seniors. Future assessments of public transportation incentive programs that may affect the travel behaviour of seniors may become more prevalent in literature as Baby Boomers enter into the age of retirement. 


\section{Appendix 1: Survey}

In 2012, Oakville Transit implemented a ride for free transit program on Mondays. This has allowed residents over the age of 65 years to travel all day on all bus routes every Monday at no charge.

The following is a short survey for a Master's research project at Ryerson University. This research has two goals. First, it will look at senior perspectives and their behaviour towards public transit and ride for free transit program in Oakville, Ontario. Second, this research will determine if a ride for free transit program has decreased auto-dependency and increased public transportation ridership.

To participate, you must be over the age of 65 as this research is focusing on the senior citizen mobility in Oakville, Ontario. This information and your identity will be kept confidential. Only the researcher and the supervisor will have access to this data. If at any time you feel uncomfortable, you may decline to answer any questions or to stop the survey.

Thank you for your participation!

Survey: Ride for Free Transportation Program

This survey is estimated to take 3-5mins to complete. Please answer the following questions by circling your response or filling in the blanks:

1) How many years have you lived in the Town of Oakville:

2) Do you have access to a personal vehicle?

As a driver
a) Yes
b) No
a) Yes
b) No

As a passenger

3) How many times a week do you use a personal vehicle (as a driver or passenger) to go somewhere?
a) Never use personal vehicle
b) Less than once a month
c) More than once a month, but less than once a week
d) One to two days a week
e) Three to four days a week
f) Five or more days a week

4) How many times a week do you take Oakville Transit public transportation to go somewhere?
a) Never use public transit
b) Less than once a month
c) More than once a month but less than once a week
d) One to two days a week
e) Three to four days a week
f) Five or more days a week

5) Why do you take public transportation? (circle all that apply)

${ }^{* *}$ Please skip this question if you NEVER use public transit

a) It's cheaper than driving (i.e. saves money on fuel)

b) It is a more convenient mode of transportation than automobile for me

c) I like being able to take public transportation by myself

d) Taking transit is good for the environment 
e) Taking transit is good for my health

f) Other:

6) Why do you NOT take public transportation? (circle all that apply)

** Please skip this question if you use public transportation.

a) It is not accessible in my daily routine

b) The fare is expensive

c) It's too slow

d) Not convenient

e) Other:

7) Are you aware of Oakville Transit's seniors ride for free program which is offered on Mondays?
a) Yes
b) No

8) Has the seniors ride for free program made a difference in your transit use?
a) Yes
b) No

9) Do you use public transit more or less than before the program was implemented?
a) More
b) Less
c) No change

10) Do you use Oakville Transit on days when the seniors ride for free service is not offered?
a) Yes
b) No

11) You would be impacted if this ride for free transit service was no longer available to you.
a) Strongly Agree
b) Agree
c) Neutral
d) Disagree
e) Strongly Disagree

12) How has this ride for free transportation program changed your transportation behaviour (circle all that apply)?
a) No change
b) I drive/take a ride in a car less than before
c) I take public transit more than before
d) I walk/cycle more than before
e) I take another mode of transportation more than before (Please state other mode of transportation)

13) Demographic questions:

a) Please circle. Gender: $M$ or $F$

b) Where do you live (postal code or major intersection)?

c) What is your age range? 
i) 65 to 74

ii) $75-84$

iii) $85+$

d) What is your highest level of education attainment?

i) No high school

ii) High school

iii) Post-secondary

iv) Certificate

v) Trades

vi) Other

vii) Prefer not to say

e) What is your individual income level?

i) Low (less than $\$ 40,000$ )

ii) $\operatorname{High}(\$ 40,000$ or more $)$

iii) Prefer not to say

f) What is your living arrangement?

i) Live with partner

ii) Live alone

iii) Live with family

iv) Other

g) What language do you speak at home?

i) Please State:

ii) Prefer not to say

14) Future Participation

Would you be willing to participate in an interview in October-December, 2014 to discuss your experience with Oakville's ride for free transit program and how it has changed or not changed your travel behaviour?

Interview dates and locations will be announced as soon as they become available. Interviews will last from 20-30mins.

a) No, I am not available for an interview.

b) Yes, I am available for an interview. Please provide the following:

- Name:

- E-mail address:

- Phone number:

This information and your identity will be kept confidential and will only be used to contact willing participants. Only the researcher and supervisor will have access to this information.

You have now completed this survey.

Thank you for your knowledge!

Please return this survey to the researcher. 


\section{Appendix 2: Interview Guide}

Demographic Information and Interview Guide:

You have participated in the questionnaire for this research project: Senior Perspectives towards ride for free transit programs. We will further discuss your experience with Oakville's ride for free transit program. We will also talk about your daily travel patterns and if this program has helped to reduce your car usage and increased your transit ridership.

Please remember that there are no right or wrong answers. We're here to talk about your experience.

This interview will be recorded and transcribed later. The information collected and your identity will be kept confidential. Only myself and my supervisor will have access to this data. If at any time you feel uncomfortable, you may decline to answer any question or to stop this interview.

1. Describe what a typical day looks like for you.

a. Where do you go?

b. How do you get there?

2. What do you like / do you not like about driving?

a. Have you ever opted to take public transportation over driving? Why or why not?

3. If you go somewhere, would you take public transportation?

a. What motivates you to take public transportation?

b. What prevents you from taking public transportation?

4. Tell me about your experience about the town of Oakville's ride for free transportation program.

a. What did you like or not like about your experience(s).

b. Why have you used this service? / Why have you not used this service?

c. How would you be impacted if this service was no longer available to you?

d. How has this service changed your transportation behaviour?

i. Do you think that you use public transportation more, the same or less?

ii. How has this service impacted the frequency of you using other modes of transportation?

e. What do you think that the city could do to better improve this program that would make you or others take this service more?

f. In the future, do you think that you will use this service more, the same or less? Why?

5. Is there anything else that you think that I should know?

Thank you for your participation! 


\section{REFERENCES}

Alsnih, R. and Hensher, D. (2007). The mobility and accessibility expectations of seniors in an aging population. Transportation Research Part A, 37, 903-916.

Cao, X., Mokhtarian, P. L. \& Handy, S. L. (2010). Neighborhood design and the accessibility of the elderly: An empirical analysis in northern California. International Journal of Sustainable Transportation, 4 (6), 347-371.

CHASS. (2013). Canadian Census Analyser. 2011 National Household Survey (NHS) Profile Files. Retrieved from http://dc1.chass.utoronto.ca/cgibin/census/2011nhs/displayCensus.cgi?year=2011\&geo=prov .

Chaudhury, H., Mahmood, A., Michael, Y., Campo, M. and Hay, K. (2012). The influence of neighbourhood residential density, physical and social environments on older adults' physical activity: An exploratory study in two metropolitan areas. Journal of Aging Studies, 26, 35-43.

Chen, W. H. (2010). Exploring Travel Characteristics and Factors Affecting the Degree of Willingness of Seniors in Taiwan to Use an Alternative Service Bus. Transportation Research Record: Journal of the Transportation Research Board, 2182(1), 71-78.

Codiac Transpo. (2014). City of Moncton. Retrieved from http://www.codiactranspo.ca/Home.htm accessed 04/18/14.

Corburn, J. (2003). Bringing Local Knowledge into Environmental Decision Making: Improving Urban Planning for Communities at Risk. Journal of Planning Education and Research, 22: 420-433.

Coronini-Cronberg, S., Millett, C., Levarty, A. and Webb, E. (2012). The Impact of a Free Older Persons' Bus Pass on Active Travel and Regular Walking in England. The American Journal of Public Health, 102(11), 2141-2148.

Cvitkovich, Y., and Wister, A. (2001). The importance of transportation and prioritization of environmental needs to sustain well-being among older adults. Environment and Behavior, 33: 809-829.

Davey, J. (2007). Older people and transport: coping without a car. Ageing and Society, 27, 49-65.

Federation of Canadian Municipalities. (2013). Canada's Aging Population: The Municipal Role in Canada's Demographic Shift. Retrieved from http://www.fcm.ca/Documents/reports/FCM/canadas_aging_population_the_municipal _role_in_Canadas_demographic_shift_en.pdf.

Franke, T., Tong, C., Ashe, M.C., McKay, H., Joanie, S. and The Walk The Talk Team. (2013). The secrets of highly active older adults. Journal of Aging Studies, 27(4), 393409.

Free public transit for seniors in Laval - the STL launches horizon 65 +. (2014, Apr 01). Canada NewsWire. Retrieved from 
http://ezproxy.lib.ryerson.ca/login?url=http://search.proquest.com/docview/1511565357 ?accountid=13631 accessed 04/20/14.

George, V. E. (2000, Oct 09). Transit socks it to seniors. Edmonton Journal. Retrieved from http://ezproxy.lib.ryerson.ca/login?url=http://search.proquest.com/docview/252860244? accountid=13631 accessed 04/20/14.

Grant, J., and Curran, A. (2007). Privatized suburbia: the planning implications of private roads. Environment and Planning B: Planning and Design, 34(4), 740-754.

Greene, J. C., Caracelli, V. J., \& Graham, W. F. (1989). Toward a conceptual framework for mixed-method evaluation designs. Educational evaluation and policy analysis, 11(3), 255-274.

Halton Region. (2007). The Quality of Life for Seniors in Halton: A Guide for Future Planning. Retrieved from www.halton.ca/common/pages/UserFile.aspx?fileld=14752.

Halton Region. (2013). Chair's Corner - Halton Region, Ontario. Retrieved from https://haltonchair.wordpress.com/category/age-friendly-communities/.

Halton Region. (n.d.). John R. Rhodes Seniors Residence - Oakville. Retrieved from http://halton.ca/cms/One. aspx?portalld=8310\&pageld=119188.

Halton Region. (n.d.). Subsidized Passes for Low Income Transit. Retrieved from http://www.halton.ca/cms/One.aspx?portalld=8310\&pageld=66697

Hensher, D. (2007). Some Insights into the Key Influences on Trip-Chaining Activity and Public Transport Use of Seniors and the Elderly. International Journal of Sustainable Transportation, 1, 53-68.

Hildebrand, E. (2003). Dimensions in elderly travel behavior: A simplified activity-based model using lifestyle clusters. Transportation, 30, 285-306.

Hodge, G. (2008). The Geography of Aging: Preparing Communities for the Surge in Seniors. Montreal, QC: McGill-Queen's University Press.

Jones, A., Goodman, A., Roberts, H., Steinbach, R. and Green, J. (2013). Entitlement to concessionary public transport and wellbeing: a qualitative study of young people and older citizens in London, UK. Social Science \& Medicine, 91, 202.

Kennedy, C. A. (2002). A comparison of the sustainability of public and private transportation systems: Study of the Greater Toronto Area. Transportation, 29(4), 459-493.

Kerr, J., Rosenberg, D. and Frank, L. (2012). The Role of the Built Environment in Healthy Aging: Community Design, Physical Activity, and Health among Older Adults. Journal of Planning Literature, 27(1), 43-60.

Kim, S. (2011). Transportation Alternatives of the Elderly After Driving Cessation. Transportation Research Record: Journal of the Transportation Research Board, 2265, 170-176. 
Krever, W. (2010). Strategic Plan for Oakville Seniors Services. Town of Oakville. Retrieved from Oakville Senior Service Staff.

Ladd, Art. (2012). Stranded in Suburbia. Canadian Centre for Policy Alternatives Manitoba Office. Retrieved from https://www.policyalternatives.ca/sites/default/files/uploads/publications/Manitoba\%20 Office/2012/02/Suburbia\%20final.pdf.

Lea, D. (2013, Nov 28). Free Transit Day for seniors up for budget debate. Oakville Beaver, p. 13. Retrieved from http://images.halinet.on.ca/Oakvillelmages/Images/OI002464332pf_0013.pdf .

Lightstone, M. (2011, Oct 26). No free rides for Halifax seniors. Herald News. Retrieved from http://thechronicleherald.ca/metro/27289-no-free-rides-halifax-seniors accessed 04/20/14.

Many benefits to free transit day for seniors. (2012, Dec 04). Oakville Beaver. Retrieved from http://ezproxy.lib.ryerson.ca/login?url=http://search.proquest.com/docview/1221934760 ?accountid=13631 accessed 04/20/14.

Michael, Y. L., Green, M. K., \& Farquhar, S. A. (2006). Neighborhood design and active aging. Health \& place, 12(4), 734-740.

MississaugaHaltonHealthLine. (2015). Income Tax Clinics Oakville. Retrieved from http://www.mississaugahaltonhealthline.ca/displayservice. $\operatorname{aspx}$ ?id=111121.

Moore, N. (2008, Jul 02). Seniors now get a free ride from Codiac Transit; Pilot Program offers free bus rides for tri-community seniors over 65 every Wednesday this summer. The Times - Transcript. Retrieved from http://ezproxy.lib.ryerson.ca/login?url=http://search.proquest.com/docview/422990771? accountid=13631 accessed 04/20/14.

National Household Data. (2011). NHS Profile. Retrieved from http://www12.statcan.gc.ca/nhs-enm/2011/dp$\mathrm{pd} / \mathrm{prof} /$ details/page.cfm?Lang=E\&Geo1=CSD\&Code1=3524001\&Data=Count\&Search Text=oakville\&SearchType=Begins\&SearchPR=01\&A1=All\&B1=All\&Custom =\&TABID= 1.

Neuman, W. L. (2011). Social Research Methods: Qualitative and Quantitative Approaches. 7th ed. Boston, MA: Pearson.

Newbold, K., Scott, D., Spinney, J., Kanaroglou, P., and Páez, A. (2005). Travel behavior within Canada's elderly population: A cohort analysis. Journal of Transport Geography, 13: 340-351.

Northcott, H. and Petriuk, C. (2013). Trends in the residential mobility of seniors in Canada, 1961-2006. The Canadian Geographer, 57(1), 43-55.

Novek, S., \& Menec, V. H. (2014). Older adults' perceptions of age-friendly communities in Canada: a photovoice study. Ageing and Society, 34(06), 1052-1072. 
Oakville Transit (2012). Pilot Analysis Appendix A. Retrieved from https://securepwa.oakville.ca/sirepub/cache/107/yjxs0dkjg5cszoaiib5tq5s3/231100020 82015122015421.PDF.

Oakville Transit (2012). Senior Survey Results Appendix B. Retrieved from https://securepwa.oakville.ca/sirepub/cache/107/yjxs0dkjg5cszoaiib5tq5s3/231101020 82015122311420.PDF.

Oakville Transit. (2012). Budget Committee Report: Pilot Results - Free Transit for Seniors. Retrieved from https://securepwa.oakville.ca/sirepub/cache/107/yjxs0dkjg5cszoaiib5tq5s3/231099020 82015122016357.PDF.

Oakville Transit. (2014). Fares. Retrieved from http://www.oakvilletransit.com/fares.html accessed 04/20/14.

Oakville Transit. (2014). Transit Facts. Retrieved from http://www.oakvilletransit.com/transitfacts.html.

Oakville Transit. (2015). Annual Accessibility Plan. Retrieved from http://www.oakvilletransit.com/assets/transit/ot-accessibility-plan-2015.pdf.

Oakville Transit. (2015). Oakville Transit celebrates more than three million rides in 2014. Retrieved from http://www.oakvilletransit.com/tnr-15jan12.html.

OC Transpo. (2014). Senior Riders. Retrieved from http://www.octranspo1.com/riding-with-octranspo/senior_riders accessed 04/20/14.

Open Parliament. (n.d.). Bill C-449 (Historical); Free Public Transit for Seniors Act. Retrieved from http://openparliament.ca/bills/40-3/C-449/ accessed 04/20/14.

OPPI - Ontario Professional Planning Institute. (2009). Healthy Communities and Planning for Age Friendly Communities: A Call to Action. Retrieved from http://ontarioplanners.ca/PDF/Healthy-Communities/2009/Call-to-Action-Age-FriendlyCommunities-June-18-20.aspx.

Páez, A., Scott, D., Potoglou, D., Kanaroglou, P., and Newbold, K. (2007). Elderly mobility: Demographic and spatial analysis of trip making in the Hamilton CMA, Canada. Urban Studies, 44:123-146.

PRESTO. (2014). Learn about PRESTO. Retrieved from https://www.prestocard.ca/enUS/Pages/ContentPages/AboutPresto.aspx.

Public Health Agency of Canada. (2010). The Chief Public Health Officer's Report on The State of Public Health in Canada 2010, Chapter 3. Retrieved from http://www.phacaspc.gc.ca/cphorsphc-respcacsp/2010/fr-rc/cphorsphc-respcacsp-06-eng.php.

Richard, L., Gauvin, L., Gosselin, C., \& Laforest, S. (2009). Staying connected: neighbourhood correlates of social participation among older adults living in an urban environment in Montreal, Quebec. Health Promotion International, 24(1), 46-57. 
Rittner, B. and Kirk A. Health Care and Public Transportation Use by Poor and Frail Elderly. Social Work, 40(3), p. 365-373.

Rosenbloom, S. (2001). Sustainability and automobility among the elderly: An international assessment. Transportation, 28 ( 4 ), 375-408.

Saleebey, D. (1996). The strengths perspective in social work practice: Extensions and cautions. Social Work, 41(3), 296-305.

Schwarzlose, A., Mjelde., Dudensing, R., Jin, Y., Cherrington, L., Chen, J. (2014). Willingness to pay for public transportation option for improving the quality of life of the rural elderly. Transportation Research Part A, 61, p. 1-14.

Scott, D., Newbold, K., Spinney, J., Mercado, R., Paez, A. and Kanaroglou, P. (2005). Changing mobility of elderly urban Canadians, 1992-1998. Centre for Spatial Analysis - Working Paper Series.

Scott, D., Newbold, K., Spinney, J., Mercado, R., Paez, A. and Kanaroglou, P. (2009). New Insights into Senior Travel Behaviour: The Canadian Experience. Growth and Change, 40(1), 140-168.

Smith, B. and Hiltner, J. (1988). Who are the Elderly Users of Public Transportation? A Case Study in Toledo, Ohio. The Journal of Applied Gerontology, 7(4), 504-513.

Spinney, J., Scott, D., and Newbold, K. (2009). Transport mobility benefits and quality of life: A time-use perspective of elderly Canadians. Transport Policy, 16(1), 1-11.

Statistics Canada. (2001). Community Profiles. Retrieved from http://www12.statcan.ca/english/profil01/CP01/Details/Page.cfm?Lang=E\&Geo1=CSD \&Code1 $=3524001 \&$ Geo2 $=P R \&$ Code2 $=35 \&$ Data $=$ Count $\&$ SearchText=oakville \&Search Type=Begins\&SearchPR=35\&B1=All\&Custom $=$.

Statistics Canada. (2006). 2006 Community Profiles. Retrieved from https://www12.statcan.gc.ca/census-recensement/2006/dp-pd/prof/92-

591/details/Page.cfm?Lang=E\&Geo1=CSD\&Code $1=3524001 \& G e 02=P R \& C o d e 2=35 \&$

Data $=$ Count $\&$ SearchText=oakville\&SearchType=Begins $\&$ SearchPR=01\&B1=All\&Custo $\mathrm{m}=$

Statistics Canada. (2011). 2011 Community Profiles. Retrieved from http://www12.statcan.gc.ca/census-recensement/2011/dp$\mathrm{pd} / \mathrm{prof} / \mathrm{details} /$ page. $\mathrm{cfm}$ ?Lang=E\&Geo1=CSD\&Code $1=3524001 \&$ Geo2=CD\&Code2=3 $524 \&$ Data $=$ Count \&SearchText=0akville\&SearchType=Begins\&SearchPR=01\&B1=All\& Custom $=\& T A B I D=1$.

Suen, S. L., \& Sen, L. (2004). Mobility options for seniors. Transportation in an ageing society: A Decade of Experience. Proceedings, 27, 97-113.

Town of Oakville. (2014). Seniors. Retrieved from http://www.oakville.ca/culturerec/programsseniors.html.

Transport, C. (2010). Bus Routes For The Elderly. Ottawa, ON, CAN: Transport Canada. 
Transportation Systems Center. (1974). Demand-Responsive Transportation. Cambridge, Massachusetts.

Turcotte, M. (2006). Seniors' access to transportation. Canadian Social Trends, 82, 43.

Turcotte, M. (2012). Profile of senior's transportation habits. Canadian Social Trends, 11(008$\mathrm{X}), 3-16$.

Turcotte, M. and Schellenberg, G.(2006). A portrait of seniors in Canada. Retrieved from http://www.statcan.gc.ca/pub/89-519-x/89-519-x2006001-eng.htm.

World Health Organization. (2007). Global Age Friendly Cities: A guide. Retrieved from http://www.who.int/ageing/publications/Global_age_friendly_cities_Guide_English.pdf. 